\title{
EMBRACING A NEW ERA OF INEFFECTIVE ASSISTANCE OF COUNSEL
}

\author{
Justin F. Marceau*
}

\begin{abstract}
The recent decisions in Missouri v. Frye and Lafler v. Cooper represent a seismic shift in the Court's right to counsel jurisprudence. No longer is the right to counsel limited to protecting the fairness and adequacy of the trial. Although these two cases arose in the plea bargaining context, the doctrinal shift may have its greatest impact in cases where plea bargaining is not at issue. This Article identifies the salient features of this new-non-trial oriented-conception of the right to counsel and explains its far-reaching impacts on the day-to-day practice of criminal law. Specifically, this Article explains the import of the newly minted right to effective assistance as it relates to a variety of procedural constitutional rights, including speedy trial, pretrial detention, double jeopardy, and jury selection rights. The explicit recognition that the right to counsel is not only, or even primarily a trial or truth protecting right promises to be a staggeringly important constitutional event.
\end{abstract}

\section{INTRODUCTION}

No longer is the right to counsel limited to protecting the fairness and adequacy of the trial itself. With the Court's decisions in Missouri v. Frye ${ }^{1}$ and Lafler $v$. Cooper, ${ }^{2}$ a new era in the jurisprudence of the Sixth Amendment has begun. This Article identifies the salient features of this new-non-trial oriented-conception of the right to counsel and explains its far-reaching impacts on the day to day practice of criminal law. Frye and Lafler represent the two most significant ineffective assistance of counsel cases since the right was first recognized in Strickland $v$. Washington. ${ }^{3}$ In view of the fact that ineffective

* I am grateful to Rebecca Aviel, Alan Chen, and Ian Farrell for their insightful comments and assistance with this project. I am also indebted to Hermine Kallman, Neal McConomy, and Gabriel Olivares for their research assistance. I would also like to thank the exceptional team of editors that worked on this Article. At the time of writing this article, certiorari had not yet been granted in Lafler and Frye. Only because of the patience and flexibility of this journal was I able to adapt the Article to reflect the import of these decisions on my thesis.

$1 \quad$ No. 10-444, slip op. (U.S. Mar. 21, 2012).

2 No. 10-209, slip op. (U.S. Mar. 21, 2012).

3466 U.S. 668 (1984). See Lafler v. Cooper, No. 10-209, slip op. at 1 (U.S. Mar. 21, 2012) (Scalia, J., dissenting) (describing the two cases as opening "a whole new field of constitutionalized criminal procedure"); see Lafler v. Cooper, No. 10-209, slip op. at 2 (U.S. Mar. 21, 2012) (Scalia, J., dissenting) (noting that the holding is certainly "a new rule of law" for purposes of constitutional retroactivity); see also Missouri v. Frye, No. 10-444, slip op. at 5 (U.S. Mar. 21, 2012) (Scalia, J., dissenting) (describing the cases as "inconsistent with the Sixth Amendment and decades of our precedent"). In describing these decisions as 
assistance of counsel is "by far the most common basis for relief sought in habeas petitions," ${ }^{4}$ a significant shift in the Strickland doctrine promises to have immediate and far-reaching implications.

The underlying question in Frye and Lafler was whether the right to counsel would adapt to reflect the reality of modern criminal practice, or whether the Sixth Amendment would serve only to protect against unfair trials. ${ }^{5}$ That is to say, given that criminal litigation is increasingly front-loaded such that the trial is no longer the main event, ${ }^{6}$ the question was whether the right to effective assistance would extend so as to ensure competent representation even when the reliability or fairness of the trial itself was not at issue. The Frye and Lafler decisions were decided on the same day, both were 5-4 votes, both were authored by Justice Kennedy, and both unequivocal-

representing a major development in the Sixth Amendment law, I am mindful of the fact that most defendants will not obtain relief for errors of counsel at the plea bargaining stage. Nonetheless, the value of these decisions in reframing the scope of the right away from trial and guilt and in the direction of general fairness promises to be significant. Moreover, the symbolic and norm-shaping impact of this sort of decision cannot be understated. Cf. John G. Douglass, Can Prosecutors Bluff? Brady v. Maryland and Plea Bargaining, 57 CASE W. RES. L. REV. 581, 589-90 (2007) ("Despite the Court's narrow definition of materiality, Brady's symbolic power in the pretrial context remains stronger prosecutors want to avoid Brady problems altogether. Indeed, Brady's greatest value may be symbolic.").

4 Keith Cunningham-Parmeter, Dreaming of Effective Assistance: The Awakening of Cronic's Call to Presume Prejudice from Representational Absence, 76 TEMP. L. REv. 827, 832 (2003) (citing U.S. Dep'T of Justice, Bureau of Justice Statistics, Federal Habeas Corpus ReVIEW Challenging STATe Court Criminal Convictions 14 (1995)).

5 The right to counsel is generally regarded as a gateway right. The commentary and case law on this point is too vast to fairly survey, but a few notable examples illustrate the point. See, e.g., Maine v. Moulton, 474 U.S. 159, 170 (1985) (explaining that the right to counsel "cannot be limited to participation in a trial" because deprivations of this right during "the period prior to trial may be more damaging than denial of counsel during the trial itself”); United States v. Ash, 413 U.S. 300, 309 (1973) (recognizing the right to counsel as fundamentally minimizing the "imbalance in the adversary system"); United States v. Wade, 388 U.S. 218, 226 (1967) (celebrating the right to counsel for ensuring the defendant "need not stand alone against the State at any stage of the prosecution, formal or informal"); Gideon v. Wainwright, 372 U.S. 335, 344 (1963) (emphasizing that the right to counsel is a necessity, not a luxury); see also Stephen B. Bright, Turning Celebrated Principles into Reality, CHAMPION, Jan./Feb. 2003, at 6 (noting that it is commonplace for "leaders of the judiciary, legal profession and government [to] give speeches" emphasizing and glorifying the ideal of the right to counsel); James J. Tomkovicz, An Adversary System Defense of the Right to Counsel Against Informants: Truth, Fair Play, and the Massiah Doctrine, 22 U.C. DAVIS L. REV. 1, 40 (1988) ("Counsel is the central component of the system, the glue that holds it together, and the protector of other guarantees.").

6 Missouri v. Frye, No. 10-444, slip op. at 7 (U.S. Mar. 21, 2012) ("The reality is that plea bargains have become so central to the administration of the criminal justice system" it is no longer accurate to describe pretrial proceedings such as plea bargaining as an "adjunct to the criminal justice system; it is the criminal justice system." (internal citation omitted)). 
ly rejected, trial-centered conception of the right to counsel. ${ }^{7}$ By unequivocally rejecting a cramped, formulistic view of the right to counsel that is oriented exclusively towards protecting the innocent and the integrity of the trial, these decisions reflect a seismic shift in Sixth Amendment jurisprudence. ${ }^{8}$

The purpose of this Article is to analyze the breadth and significance of the Court's rejection of the conclusion that "the sole purpose of the Sixth Amendment is to protect the right to a fair trial." Specifically, this Article explains the import of the newly-minted right to effective assistance as it relates to a variety of pretrial constitutional rights. In other words, this Article creates a road map for understanding the new era of right to counsel claims by cataloguing the numerous issues of procedural litigation which for years have divided lower courts and appeared unanswerable.

The Article proceeds in four parts. Part One provides an overview of the right to counsel, particularly as the right has developed with regard to the protection of pretrial rights. Part Two examines the dichotomous readings of Strickland that existed in the literature and published decisions and that were competing for legitimacy during the decades preceding this Term's decisions in Frye and Lafler. In Part Three, the reasoning behind the Frye and Lafler cases is discussed, and the role of these decisions in markedly expanding the scope of the Strickland rule is emphasized. Finally, in Part Four, the practical implications of the new era of effective assistance are discussed. Specifically, Part Four analyzes an array of procedural rights-jury selection, speedy trial, pretrial detention-and demonstrates that the Court's decision to definitively sever the right to

7 Both Lafler $v$. Cooper and Missouri v. Frye involve plea bargains, a topic not directly taken up by this paper. Prior to these decisions, other commentators had thoroughly canvassed this discrete topic. See, e.g., David A. Perez, Note, Deal or No Deal? Remedying Ineffective Assistance of Counsel During Plea Bargaining, 120 YALE L.J. 1532, 1539 (2011) (explaining that plea bargaining is a "critical stage of the prosecution after adversarial proceedings have begun" to which the Sixth Amendment's right to counsel attaches); Paul J. Sampson, Note, Ineffective Assistance of Counsel in Plea Bargain Negotiations, 2010 BYU L. REV. 251, 253, 266 (arguing that the Sixth Amendment ensures a fair trial, not effective plea bargaining); Leigh Tinmouth, Note, The Fairness of a Fair Trial: Not Guilty Pleas and the Right to Effective Assistance of Counsel, 50 B.C. L. REV. 1607, 1635 (2009) (discussing the right to effective assistance of counsel for not guilty pleas).

8 Just last Term, the Court strongly suggested that non-trial based claims of ineffective assistance of counsel are of a lower tier, and less likely to warrant relief. Premo v. Moore, 131 S. Ct. 733, 742 (2011) (concluding that the absence of a record in pretrial, plea negotiations justifies a heightened deference to counsel in the pretrial context).

9 Lafler v. Cooper, No. 10-209, slip op. at 6 (U.S. Mar. 21, 2012). 
counsel from concerns about the reliability of a guilty verdict is a staggeringly important constitutional event.

\section{OVERVIEW OF THE PRETRIAL RIGHT TO COUNSEL}

At common law a defendant charged with a felony was not entitled to the assistance of counsel, even if he was willing and able to retain and pay for an attorney. ${ }^{10}$ A defendant facing felony charges was, with a few narrow exceptions, prohibited from obtaining the assistance of counsel. ${ }^{11}$ The Sixth Amendment expressly rejected the harshness of this common law approach and recognized, in relevant part, that "[i]n all criminal prosecutions, the accused shall enjoy the right... to have the Assistance of Counsel for his defence." ${ }^{12}$ The right to counsel granted to defendants by the Sixth Amendment was, therefore, first and foremost, a rejection of the common law practice of prohibiting representation in felonies. In this way, the Sixth Amendment, as initially conceived, was effectively a negative liberty. ${ }^{13}$

However, as Professor Pamela Metzger has explained, the "modern Sixth Amendment counsel guarantee is, and should be, a radically different guarantee than that contemplated by the Framers." ${ }^{14}$ Professor Metzger has made a compelling case for understanding the history of the right to counsel as a history dominated by doctrinal development such that the right was constantly changing to respond to the current "realities of criminal procedure." Among the most important adaptations of the right to counsel was the shift to an understanding of the Sixth Amendment as bestowing affirmative rights ra-

10 As one scholar has noted, "[t] he right to counsel does not have the illustrious AngloAmerican heritage one might expect." Tomkovicz, supra note 5, at 10.

11 Defendants were entitled to counsel if they were charged under the Treason Act of 1695. See Faretta v. California, 422 U.S. 806, 824 \& n.24 (1975) (citing the express language of the English statute providing for the assistance of counsel).

12 U.S. CONST. amend. VI. Notably, the right to counsel, even as a negative liberty, did not extend to persons charged with state crimes; "states made their own decisions about access to counsel" insofar as the Sixth Amendment did not apply to the states. Pamela R. Metzger, Beyond the Bright Line: A Contemporary Right-to-Counsel Doctrine, 97 Nw. U. L. REV. 1635, 1641 (2003).

13 See, e.g., Powell v. Alabama, 287 U.S. 45, 60-66 (1932) (summarizing the common law rule barring persons accused of felonies from obtaining counsel and examining the Sixth Amendment response to this rule); see also Padilla v. Kentucky, 130 S. Ct. 1473, 1495 (2010) (Scalia, J., dissenting) ("The Sixth Amendment as originally understood and ratified meant only that a defendant had a right to employ counsel, or to use volunteered services....").

14 Metzger, supra note 12, at 1637.

15 Id. 
ther than purely negative liberties. ${ }^{16}$ The right to counsel as currently conceived requires that the court affirmatively appoint counsel for all indigent persons facing felony charges unless the defendant knowingly and voluntarily waives the right to representation. ${ }^{17}$

Notably, the affirmative right to counsel "cannot be satisfied by mere appointment." 18 Because the right to counsel serves as the "glue that holds" the system of justice together, ${ }^{19}$ the right to the appointment of a lawyer would be rendered largely symbolic and hollow unless the right to counsel includes the right to the effective assistance of counsel. Stated another way, if the right to counsel is designed to aid the adversarial system in producing "just results," then a logical corollary of the right to appointment of counsel is the right to effective assistance from counsel; the former right does not serve its

16 At this point the affirmative right to counsel is largely beyond controversy. See Abe Krash, Remarks at the Conference on the 30th Anniversary of the United States Supreme Court's Decision in Gideon v. Wainwright: Gideon and the Public Service Role of Lawyers in Advancing Equal Justice (Mar. 18, 1993), in 43 AM. U. L. REv. 1, 27 (1993) (“[C]ritics have urged the Supreme Court to limit or to overrule various decisions of the 1950s and the 1960 s with respect to the rights of accused persons, but no responsible voice-no responsible voice-is heard today urging that the Gideon decision should be overruled."). Even leading textualist-originalists like Akhil Amar have summarized the affirmative right to counsel as follows: "The text of the counsel clause can be read either way. But structural arguments strongly support the modern Court's view that indigent defendants have a right to the assistance of counsel at government expense." AKHIL REED AMAR, THE Constitution ANd Criminal Procedure: First PRINCIPLes 140 (1997).

17 See Gideon v. Wainwright, 372 U.S. 335, 344 (1963) ("The right of one charged with crime to counsel may not be deemed fundamental and essential to fair trials in some countries, but it is in ours."); Johnson v. Zerbst, 304 U.S. 458, 463-64 (1938) ("The Sixth Amendment withholds from federal courts, in all criminal proceedings, the power and authority to deprive an accused of his life or liberty unless he has or waives the assistance of counsel. ... A waiver is ordinarily an intentional relinquishment or abandonment of a known right or privilege."). Even a defendant facing only misdemeanor charges is entitled to the appointment of counsel if he is sentenced to actual incarceration. Argersinger v. Hamlin, 407 U.S. 25, 37 (1972). Moreover, a defendant wishing to waive his right to counsel faces a number of hurdles. See Faretta v. California, 422 U.S. 806, 835 (1975) (noting the loss of "traditional benefits associated with the right to counsel" and "the dangers and disadvantages of self-representation"); 3 WAYNE R. LAFAVE ET AL., CRIMINAL PROCEDURE $\$ 11.5$ (d) (3d ed. 2011) (noting that "[t]he defendant in Faretta made a clear and unequivocal request to proceed pro se, and courts insist upon such a request as a prerequisite for the exercise of the right of self-representation" and explaining that there is even a heightened standard of competence for persons who wish to proceed without counsel at trial).

18 Kimmelman v. Morrison, 477 U.S. 365, 377 (1986) (citing Avery v. Alabama, 308 U.S. 444, 446 (1940), as cited by Walter V. Schaefer, Federalism and State Criminal Procedure, 70 HARV. L. REv. 1, 8 (1956), for the proposition that the right to counsel is the keystone right for all of criminal procedure); see also United States v. Cronic, 466 U.S. 648, 655 (1984) (citing Avery, 308 U.S. at 446) (concluding that "mere formal appointment" does not satisfy the text of the Sixth Amendment, which requires "assistance" of counsel).

19 Tomkovicz, supra note 5 , at 40. 
purpose without the latter right. Consistent with this view, in Strickland $v$. Washington, the Court held that the right to appointed counsel naturally and necessarily implies a right to adequate and effective representation. $^{20}$ Strickland quelled lower court confusions as to the proper standard for evaluating ineffective assistance of counsel claims by creating a two-part test that requires a defendant to show that counsel's performance was deficient-based on an "objective standard of reasonableness" - and that he was prejudiced by the errors of counsel. $^{21}$

The existence of a right to effective representation in general, however, does not meaningfully illuminate the scope of pretrial effective assistance rights. It is clear that the right to effective assistance, in its most robust articulation, cannot apply more broadly than the right to counsel simpliciter-that is to say, where there is no right to appointed counsel, a fortiori there is no right to effective assistance of counsel. ${ }^{22}$ The right to appointed counsel is triggered only where two technical requirements are satisfied: (1) the right to counsel must have attached; and (2) the proceeding in question must be at a critical stage.

The threshold question of attachment is understood as enforcing the textual requirement that the Sixth Amendment only applies to "criminal prosecutions," and thus the question of when the right attaches is an inquiry about when a criminal prosecution begins. Recently, the Supreme Court addressed the attachment issue and explained that a defendant's "initial appearance before a judicial officer, where he learns the charge against him and his liberty is sub-

20 Strickland v. Washington, 466 U.S. 668, 685 (1984). The Court has explained that the "right to counsel is the right to effective assistance of counsel." Id. at 686; Kimmelman, 477 U.S. at 377 (internal citations omitted).

21 Strickland, 466 U.S. at 668, 692-93. Prior to Strickland, "the Supreme Court did not offer guidance about ineffective assistance claims" and what was required was "anybody's guess." Donald A. Dripps, Ineffective Assistance of Counsel: The Case for an Ex Ante Parity Standard, 88 J. CRIM. L. \& CRIMINOLOGY 242, 272 (1997)

22 See, e.g., Coleman v. Thompson, 501 U.S. 722, 755-57 (1991) (holding that defendant had no constitutional right to counsel in a state post-conviction proceeding and, thus, could not claim ineffective assistance of counsel in such proceeding); Ross v. Moffit, 417 U.S. 600 (1974) (holding that defendant had no constitutional right to counsel in his discretionary appeal to the State Supreme Court); Emily Garcia Uhrig, A Case for A Constitutional Right to Counsel in Habeas Corpus, 60 Hastings L.J. 541, 572 (2009) ("[T] he Supreme Court has rejected any claim of ineffective assistance of counsel ... on the ground that there can be no constitutionally ineffective counsel absent a right to counsel in the first instance."). Recently, the Court has recognized that ineffective assistance of counsel during an "initial-review collateral proceeding" may serve as cause to excuse a procedural default, but the Court stopped short of recognizing a freestanding constitutional right to effective assistance. Martinez v. Ryan, No. 10-1001, slip op. at 5 (U.S. Mar. 20, 2012). 
ject to restriction, marks the start of adversary judicial proceedings that trigger attachment of the Sixth Amendment right to counsel." ${ }^{23}$ The Sixth Amendment, then, does not apply merely because the police are investigating someone, or because they have sought or obtained a warrant, or even when they make an arrest. $^{24}$ Instead, the Sixth Amendment is limited by its own terms so as not to apply "until a prosecution is commenced," 25 and the point of commencement has been recognized as a defendant's initial appearance. ${ }^{26}$

The Court's clarity in Rothgery as to when the right to counsel attaches ended three decades of confusion on this issue. Scholars and courts had spent considerable ink attempting to define the point at which a defendant faces sufficiently "formal charges" so as to indicate the beginning of a "criminal prosecution," and, thus, the attachment of the right to counsel. ${ }^{27}$ But resolving the attachment issue is only

23 Rothgery v. Gillespie Cnty., 554 U.S. 191, 213 (2008) (emphasis added); Id. at 214 (Alito, J., concurring) (agreeing with the Court's analysis and elaborating that the right to counsel can be divided into three questions-when does it apply (criminal prosecutions); who is entitled to the right (the "accused"); and what does the right guarantee (assistance of counsel for one's defense)). In contrast, Justice Clarence Thomas explained that, based on his understanding of the original meaning of the phrase "in all criminal prosecutions," the Sixth Amendment right to counsel does not apply until there are formal charges, which requires an indictment in most federal cases. Id. at 218-25 (Thomas, J., dissenting).

$24 I d$. at 198 (describing for constitutional purposes when the right to counsel attaches); see also id. (noting that the attachment of the right to counsel and the "state obligation to appoint counsel" are not necessarily coextensive insofar as the right might apply or attach even before the state has an absolute obligation to provide counsel); $i d$. at 211 (distinguishing between "the attachment question (whether formal judicial proceedings have begun) and the distinct 'critical stage' question (whether counsel must be present at a postattachment proceeding unless the right to assistance is validly waived)").

25 McNeil v. Wisconsin, 501 U.S. 171, 175 (1991). Paradoxically, the Supreme Court has held that for purposes of the Sixth Amendment speedy trial right, the criminal prosecution begins with the arrest, or the indictment, whichever comes first. U.S. v. Marion, 404 U.S. 307, 320 (1971) ("it is either a formal indictment or information or else the actual restraints imposed by arrest and holding to answer a criminal charge that engage the particular protections of the speedy trial provision of the Sixth Amendment.").

26 Rothgery, 554 U.S. at 213 (Alito, J., concurring). In Rothgery, the Court emphasized that the attachment of the right to counsel is not contingent on the title a jurisdiction prescribes to a defendant's first appearance in court. Id. at 207-08 (regarding the issue as one of "federal law" that is unaffected by the terminology used by a particular jurisdiction, and treating a Texas Article 15.17 Hearing as an initial appearance for purposes of federal law); see also The Supreme Court, 2007 Term-Leading Cases, 122 HARv. L. REv. 276, 311 (2008) (celebrating the clarity of Rothgery by noting: "The Court defined [] attachment ... in neutral terms, avoiding jargon like 'arraignment' and 'preliminary hearing' that have different definitions in different jurisdictions.").

27 See, e.g., Moran v. Burbine, 475 U.S. 412, 431 (1986) ("[T] he Sixth Amendment right to counsel does not attach until after the initiation of formal charges."); Kirby v. Illinois, 406 U.S. 682, 689 (1972) (recognizing that the right to counsel is triggered by "the initiation of adversary judicial criminal proceedings-whether by way of formal charge, preliminary 
half the battle. ${ }^{28}$ Even when the right to counsel has formally attached, there is no right to the appointment of counsel unless the proceedings in question are deemed sufficiently critical to the criminal proceeding. ${ }^{29}$ That is to say, the appointment and presence of counsel are not required unless, post-attachment, the defendant is involved in a critical stage of the criminal litigation process. Rothgery emphasized that the mere attachment of the right to counsel does not, standing alone, require appointment of counsel; the opinion warned lower courts to "avoid[] the mistake of merging the attachment question (whether formal judicial proceedings have begun) with the distinct 'critical stage' question (whether counsel must be present...)." ${ }^{30}$ The determination of the constitutional scope of a right to appointed counsel rests, therefore, on the assessment of what, other than the trial itself, constitutes a sufficiently critical stage to trigger the Sixth Amendment. ${ }^{31}$

hearing, indictment, information, or arraignment"). A leading casebook notes, "[i]t is not clear what the Supreme Court means by 'formal charge." STEPHEN A. SALTZBERG \& DANiEl J. CAPRA, AMERICAN CRIMINAL PROCEDURE: CASES AND COMMENTARY 846 (9th ed. 2010).

28 The attachment of the right to counsel, then, is a somewhat symbolic and meaningless concept. Attachment appears to merely trigger the limitations on police announced in Massiah v. United States, 377 U.S. 201, 205-06 (1964), and in this sense functions as a prophylactic negative liberty, as opposed to the affirmative right to counsel promised by the right to counsel.

29 United States v. Wade, 388 U.S. 218, 223-27 (1967), signals the beginning of the Court's willingness to recognize the need for the right to counsel to extend affirmative protections beyond the trial itself. $I d$. at 224 (explaining that at the time of ratification "there were no organized police forces" and that the changing nature of the criminal prosecution required a similarly evolving notion of the protections enshrined by the right to counsel). Wade also provides a working definition of the critical stage concept. Id. at 227 (defining critical stage as a point when assistance of counsel is necessary "to help avoid ... [potential substantial prejudice to defendant's rights]”); see also id. at 226 (“[I]n addition to counsel's presence at trial, the accused is guaranteed that he need not stand alone against the State at any stage of the prosecution, formal or informal, in court or out, where counsel's absence might derogate from the accused's right to a fair trial." (footnotes omitted)).

30 Rothgery, 554 U.S. at 211. Justice Alito wrote a separate concurrence in Rothgery primarily to explain that he did "not understand [the Court] to hold that" there is a right to appointed counsel merely because the right has attached. Id. at 213 (Alito, J., concurring).

31 Critical stages are those points during the criminal process, both in and out of court, where the presence of counsel is necessary to help the accused "in coping with legal problems or .. meeting his adversary." Id. at 212 n.16 (citing United States v. Ash, 413 U.S. 300, 313 (1973)). The Court's definitive exposition of the Sixth Amendment's phrase "criminal prosecutions" was provided in Kirby $v$. Illinois, where the Court explained that a criminal prosecution is said to exist whenever judicial proceedings have been initiated "whether by way of formal charge, preliminary hearing, indictment, information, or arraignment." 406 U.S. 682, 689-90 (1972). At times the Court has suggested that certain pretrial events were more critical to a defendant's ability to receive effective assistance of counsel than the trial itself. See, e.g., Massiah v. United States, 377 U.S. 201, 205 (1964) 
The Court has repeatedly and consistently recognized that certain pretrial events constitute critical stages that trigger the attachment and the requirement of appointment of counsel. Although the trial may be the most dramatic and exciting part of the criminal process, deprivations of the right to counsel "during the period prior to trial may be more damaging than denial of counsel during the trial itself." ${ }^{32}$ There is explicit recognition throughout the Court's Sixth Amendment jurisprudence that pretrial proceedings oftentimes "settle the accused's fate and reduce the trial itself to a mere formality." ${ }^{33}$ The A.B.A. Standards for Criminal Justice are in accord, elaborating that " $[\mathrm{e}]$ ffective representation consists of much more than the advocate's courtroom function per se." ${ }^{34}$ It is well established, for example, that certain pretrial confrontations between the police and the defendant, such as when the police interrogate or attempt to elicit incriminating statements from the defendant post-attachment, implicate the assistance of counsel rights under the Sixth Amendment. ${ }^{35}$ In short, it has long been clear that the right to appointed counsel is not merely coterminous with the right to the assistance of counsel at trial. ${ }^{36}$

In the wake of Rothgery, it is clear that "[o]nce attachment occurs, the accused at least is entitled to the presence of appointed counsel

(describing the period between arraignment until trial as "perhaps the most critical period of the proceedings" (internal citations omitted)).

32 Maine v. Moulton, 474 U.S. 159, 170 (1985); see also Kirby, 406 U.S. at 688 n.6 (confirming that it is not the case that a defendant in a criminal case has a constitutional right to counsel only at the trial itself).

33 Wade, 388 U.S. at 224.

34 American Bar Association, ABA Standards for Criminal Justice: Prosecution FunCTION AND DEFENSE FUnCTION $§ 4-4.1$ (3d ed. 1993); see also Rothgery, 554 U.S. at 212 ("Once attachment occurs, the accused at least is entitled to the presence of appointed counsel during any 'critical stage' of the postattachment proceedings...." (footnote omitted)).

35 Scholars have pointed out that the Court has failed to adequately "explain the Sixth Amendment premises that justify a pretrial right to counsel ...." James J. Tomkovicz, Reaffirming the Right to Pretrial Assistance: The Surprising Little Case of Fellers v. United States, 15 WM. \& MARY Bill RTS. J. 501, 516 (2006).

36 In Rothgery, the Court was confronted with a narrow issue. The lower federal courts had granted summary judgment against a civil plaintiff on the theory that his right to counsel had not attached at the initial hearing. 554 U.S. at 198. The Supreme Court reversed and held that an initial appearance did trigger the right to counsel, but explained that it was not deciding whether a "6-month delay in appointment of counsel" following an initial appearance "resulted in prejudice to Rothgery's Sixth Amendment rights." Id. at 213; $i d$. (Alito, J., concurring) ("I join the Court's opinion because I do not understand it to hold that a defendant is entitled to the assistance of appointed counsel as soon as his Sixth Amendment right attaches."). 
during any 'critical stage' of the post-attachment proceedings." However, the recognition that a defendant is entitled to the appointment of counsel at or shortly after the initial appearance is little more than a useless platitude if the pretrial litigation of non-trial rights is not considered a critical stage. ${ }^{38}$ The right to appointed counsel divorced from a right to effective assistance of counsel is a hollow right. And yet, surprisingly, prior to Frye and Lafler, very few definitive statements of law regarding the scope of the right to pretrial effective assistance existed in the opinions of courts or the scholarly commentary. That is to say, the Strickland right's application to the pretrial context has long suffered from uncertainty.

\section{THE FAIRNESS DICHOTOMY-RELIABILITY OF THE VERDICT OR THE FAIRNESS OF THE PROCEDURES?}

Clarity as to the scope of the Strickland right's application has long been marred by divergent understandings of the nature and purpose of the right. On the one hand, Strickland, particularly through its prejudice requirement, can be understood to preclude claims of pretrial ineffective assistance of counsel when the reliability of the trial is not in doubt. Under this narrow construction of Strickland, as developed below, many pretrial errors-failure to dismiss the indictment for delay, the failure to secure a release on bail or the failure of counsel to challenge a Batson violation-would not be cognizable bases for relief. By contrast, insofar as the right to counsel is conceived of as protecting a fairness ${ }^{39}$ that is distinct from, and in addition to, the reliability of the jury's guilt determination and the fairness of the trial itself, there is good reason to conclude that convictions secured on the basis of pretrial constitutional deficiencies caused by the errors of defense counsel are constitutionally unsound. And this would be true regardless of whether the fairness of the trial itself is directly implicated.

37 Rothgery, 554 U.S. at 212 (footnote omitted) (emphasis added).

38 One of the notable features of the Lafler decision is its definition of the phrase "critical stage" so as to include any "proceeding in which defendants cannot be presumed to make critical decisions without counsel's advice." Lafler v. Cooper, No. 10-209, slip op. at 6 (U.S. Mar. 21, 2012).

39 I use the term "fairness" throughout the Article because it appears throughout the Strickland decision itself. It is, however, no less helpful to frame the question as one of correcting injustice-that is, what constitutes an unjust conviction requiring reversal. $C f$. John C. Jeffries, Jr. \& William J. Stuntz, Ineffective Assistance and Procedural Default in Federal Habeas Corpus, 57 U. CHI. L. REv. 679, 680 (1990) (considering circumstances when errors of counsel result in an "unjust conviction"). 
In short, nothing less than the relevance of the right to counsel as a vehicle for protecting a wide range of pretrial rights is at stake. The following section details the two competing conceptions of the right to counsel by tracing their origins in Supreme Court decisions. ${ }^{40}$

Notably, the Supreme Court's guidance as to these competing models has been preciously sparse. The Supreme Court has provided seemingly contradictory messages as to which fairness orientation reflects the appropriate function of the right to counsel. Indeed, it is fair to say that over the years the right to counsel cases have exhibited something of a duality, at times embracing a robust approach to fairness that extends well beyond the merits or legitimacy of the trial, and at other times announcing a rigidly trial-centered approach to the right that focuses on accuracy and the fairness of the trial itself. Even the Strickland decision itself is susceptible to accusations of ambivalence, if not outright inconsistency, on this point.

Throughout the Strickland decision, for example, the Court stresses that any effort to "elaborate[] on the meaning of the constitutional requirement of effective assistance" must be guided by the purpose of the right, namely, "to ensure a fair trial." And in explaining that the lawyer's role is "to ensure that the trial is fair," the Court went so far as to emphasize that a fair trial is one that merely

40 Actually, three competing conceptions of the fairness protection underlying the Strickland right exist. At one extreme, there are courts and commentators who regard the right to counsel as primarily a truth-seeking and innocence serving protection. See, e.g., Amar, supra note 16, at 138-44. On the other end of the spectrum are judges and commentators, like Martin Gardner, who understand the right to counsel as serving a set of purposese.g. the privacy and integrity of the attorney client relationship-that are largely independent of procedural fairness. That is, they conceive of a right so robust that it can be violated even when no unfairness to the defendant occurs. Martin R. Gardner, The Sixth Amendment Right to Counsel and Its Underlying Values: Defining the Scope of Privacy Protection, 90 J. CRIM. L. \& CRIMINOLOGY 397, 404, 415 (2000). A second but related approach to understanding the right to counsel is the view that the right to counsel properly understood involves a "constitutionally protected professional relationship." Brooks Holland, A Relational Sixth Amendment During Interrogation, 99 J. CRIM. L. \& CRIMINOLOGY 381, 425 (2009). The idea behind this "relational" right to counsel is that the values underlying the Sixth Amendment are designed to "honor" and safeguard the relationship between a lawyer and a client, and it seems that the primary objective of this model is to construct a principled justification for abandoning the "attachment" doctrine insofar as it disadvantages defendants who are arrested or investigated prior to the commencement of formal judicial proceedings. Id. At present, lofty conceptions of the right to counsel, like that articulated by Gardner, remain primarily aspirational, and their proponents readily concede as much. The third and final understanding of the protections embodied in the right to counsel is a compromise position. Under this approach, the right to counsel only protects the fairness of the proceedings, but the fairness protection under this compromise position is sufficiently capacious as to be violated even when the underlying reliability or fairness of the trial is not in question.

41 Strickland v. Washington, 466 U.S. 668, 686 (1984). 
produces a "just result." ${ }^{42}$ Stated more directly, the Court explained that the right to counsel merely facilitates a "fair trial, a trial whose result is reliable." ${ }^{43}$ But the focus on the trial itself and on the reliability of the verdict stand in sharp contrast to other portions of Strickland that equate the right to effective assistance with a more general safeguard for the "fundamental fairness" and justness of the adversarial process. ${ }^{44}$ The latter goal-an emphasis on the general fairness of the adversarial process-reflects a broad construction of the right to counsel. ${ }^{45}$ By contrast, the orientation towards reliable results and a procedurally regular trial reflect a narrow conception of the right to counsel. ${ }^{46}$

Given the conflicting messages regarding the purpose of the right to counsel in Strickland itself, it is not surprising that other decisions from the Court as well as scholarly commentary on the issue have been hopelessly unclear, if not irreconcilable in discussing the proper scope of the Strickland right. ${ }^{47}$

45 Justice Scalia has referred to the conception of the right to counsel that safeguards rights distinct from any impact on the reliability of a verdict as a "sporting chance theory of criminal law" that is oriented towards protecting "each player[s'] . . fair chance to beat the house" rather than protecting reliable outcomes and valid convictions. Lafler v. Cooper, No. 10-209, slip op. at 13 (U.S. Mar. 21, 2012) (Scalia, J., dissenting).

46 Further ambiguity as to this point abounds in the Strickland decision. 466 U.S. 668 (1984). In one breath prejudice is defined as a reasonable probability that the "result" of the proceeding would have been different. Id. at 694. And in the next breath, the Court explains that a reasonable probability can be understood as a probability that "undermine[s] confidence in the outcome." Id. These definitions are not necessarily incompatible, but the likelihood of a different result and lack of faith or confidence in the result are not always equivalent. One could be convinced, for example, that but for counsel's errors a trial outcome would be different, perhaps because of counsel's failure to suppress evidence, and nonetheless not have any reservations or shaken confidence about the validity and reliability of the ultimate verdict. Likewise, perhaps one would lose confidence in the guilty verdict of a jury if it was revealed that the prosecutor discriminated on the basis of race in selecting the jury, and yet there is no obvious reason to believe that such a confidence-undermining unfairness inherently infects the reliability of the verdict such that there is a reasonable probability that but for the discrimination there would have been a different result. Cf. Harrington v. Richter, 131 S. Ct. 770, 791-92 (2011) (noting that there is only a slight difference between Strickland prejudice and requiring a showing that it is more likely than not that the result would have changed at trial).

47 Jeffries \& Stuntz, supra note 39, at 685-86 (describing the Court's description of the prejudice requirement's relationship to factual innocence as "mixed and inconclusive"). 


\section{A. Evidence of a Robust Approach to Fairness Prior to Frye and Lafler}

One way to conceive of the right to counsel is as a protection that extends beyond the fairness of the trial. There is commentary and case law suggesting that the right to counsel serves more than the accuracy or trustworthiness of the guilt determination. According to this view, the right to counsel ensures a level of fairness and adequacy of procedure that is not exclusively instrumentalist in its application. The right to counsel, so understood, recognizes that the accuracy, and, even the fairness of the trial, are not the only outcomes that matter - that is to say, trial outcomes and procedures "are not everything." "Prior to Lafler and Frye, there were four lines of cases suggesting that the Sixth Amendment had a fairness orientation that is not limited to the trial itself ${ }^{49}$ - Coleman $v$. Alabama ${ }^{50}$ Kimmelman $v$. Morrison, ${ }^{51}$ Massiah v United States, ${ }^{52}$ and Padilla v. Kentucky. ${ }^{53}$

First, in 1970, the Court decided Coleman v. Alabama, which addressed the right to counsel at a preliminary hearing. ${ }^{54}$ Coleman was handed down nearly fifteen years before the right to effective assistance of counsel was announced in Strickland, and the analysis is accordingly limited to the issue of whether the preliminary hearing was a critical stage for which the appointment of counsel was required. Coleman held that the preliminary hearing was a critical stage, and this conclusion alone provides an important insight into the nature of the protections of the right to counsel. ${ }^{55}$

Although the right to counsel attaches as early the initial appearance, the Court has unequivocally declared that it is not appropriate to assume that the "attachment" of the right to counsel necessarily requires the appointment of counsel. ${ }^{56}$ Instead, the right to the pres-

48 See Philip Halpern, Government Intrusion into the Attorney-Client Relationship: An Interest Analysis of Rights and Remedies, 32 BUFF. L. REV. 127, 172 (1983) ("The right to counsel embraces two separate interests: reliable and fair determinations in criminal proceedings, and treatment of defendants with dignity and respect regardless of the effect on the outcome of criminal proceedings.").

49 In one sense the pursuit of "fairness" could be regarded as instrumentalist, but it is important to note that the non-outcome focused model of fairness elaborated upon in this section includes procedural unfairness that does not impede the ultimate fairness of the trial.

50399 U.S. 1 (1970).

477 U.S. 365 (1986).

377 U.S. 201 (1964).

130 S. Ct. 1473 (2010).

Coleman, 399 U.S. at 3.

Id. at 12 (Black, J., concurring).

Rothgery v. Gillespie Cnty., 554 U.S. 191, 211 (2008) (warning against the "mistake of merging the attachment question ... with the distinct 'critical stage' question"). 
ence or appointment of counsel is limited to circumstances in which the stakes are sufficiently high so as to render the proceeding in question a critical stage of the process. ${ }^{57}$ Moreover, the right to the appointment of counsel and the right to effective assistance have so far been regarded as coextensive, such that the right to "effective assistance extends to ... any proceeding as to which there would be a constitutional right [] to appointed counsel." ${ }^{58}$ Consequently, Coleman's holding that a defendant has a right to counsel at the preliminary hearing serves as an important data point in understanding the scope of the right to pretrial effective assistance. ${ }^{59}$ So long as Coleman remains good law, courts must choose either to recognize that defendants are entitled to effective assistance of counsel at all proceedings roughly analogous to the hearing in Coleman, or take the unprecedented step of trifurcating the right to counsel into three tiers: (1) attachment; (2) appointment; and (3) effective assistance. That is to say, if a preliminary hearing is a critical stage, as the Court recognized in Coleman, then to hold that deficient performance of counsel that does not impact the fairness of the trial or the reliability of the guilt determination is not cognizable is to create a world in which: (1) some defendants are not entitled to counsel (per the Gideon rule), (2) some defendants are entitled to counsel but are not entitled to the presence of counsel at a particular proceeding (per the critical stage analysis), and (3) some defendants who are entitled to the ap-

57 Cf. United States v. Wade, 388 U.S. 218, 226 (1967) (“[I]n addition to counsel's presence at trial, the accused is guaranteed that he need not stand alone against the State at any stage of the prosecution, formal or informal, in court or out, where counsel's absence might derogate from the accused's right to a fair trial." (footnotes omitted)).

58 LAFAVE ET AL., supra note 17 , at $\$ 11.7$ (a). Just as the right to counsel implies the right to effective assistance, the absence of the right to counsel at any stage of a proceeding dictates that there can be no right to effective assistance. See, e.g., Coleman v. Thompson, 501 U.S. 722, 752 (1991) (holding that where "[t]here is no constitutional right to an attorney in state post-conviction proceedings, ... a petitioner cannot claim constitutionally ineffective assistance of counsel in such proceedings" (internal citations omitted)); Pennsylvania v. Finley, 481 U.S. 551, 557 (1987) (holding that because "[s] tates have no obligation to provide [post-conviction relief] ... fundamental fairness mandated by the Due Process Clause does not require that the State supply a lawyer as well [when the State chooses to supply such relief]" (internal citation omitted)).

59 At the very least, preliminary hearings that are similar in scope and nature to the hearing at issue in Coleman must be considered critical stages. Notably, however, leading scholars speak of Coleman in general terms as recognizing preliminary hearings as a critical stage. See 2 Joshua Dressler \& Alan C. Michaels, Understanding Criminal Procedure: ADJUDICATION $\$ 4.02$ (4th ed. 2006) ("[T] he Court has found that ... a preliminary hearing ... constitute[s] [a] 'critical stage[],' requiring the presence of counsel." (footnotes omitted)). Notably, the preliminary hearing in Coleman seems to effectively mirror the procedures of the federal preliminary hearing as defined by Federal Rule of Criminal Procedure 5.1. 
pointment and presence of counsel have no enforceable right to the effective assistance of counsel. ${ }^{60}$

Given the inevitable logic in favor of ensuring that the right to appointed counsel is meaningful, it seems undesirable and unlikely that courts will trifurcate the right to counsel by disaggregating the right to appointed counsel from the right to effective assistance. Thus, assessing the nature of the proceeding at issue in Coleman, which is understood to justify the appointment of counsel, provides critical information about the scope of the right to pretrial effective assistance. The Supreme Court summarized the Alabama preliminary hearing procedure as follows:

The preliminary hearing is not a required step in an Alabama prosecution. The prosecutor may seek an indictment directly from the grand jury without a preliminary hearing. ... [T] he sole purposes of a preliminary hearing are to determine whether there is sufficient evidence against the accused to warrant presenting his case to the grand jury and, if so, to fix bail ...

Based on this description, it seems obvious that the preliminary hearing is not primarily a safeguard on the fairness or reliability of the eventual trial. There are certain aspects of the preliminary hearing that might impact the fairness of the trial, for example, the defense counsel may use the preliminary hearing to assess the State's case "against his client" and to prepare a "defense to meet that case at the trial." ${ }^{62}$ But the central thrust of the Alabama hearing is the opportunity for counsel to secure bail for his client or to "expose fatal weaknesses in the State's case that may lead the magistrate to refuse to bind the accused over [for trial]." 63

To be sure, such probable cause testing designed to expose "weakness" in the prosecution's case, and to a lesser extent the bail determinations, will often have preciously little to do with the fairness of the trial itself. It is worth noting that the Court regarded the op-

60 Notably, this position was taken for granted by lawyers arguing in support of the State in Lafler v. Cooper. Transcript of Oral Argument at 12-13, Lafler v. Cooper, No. 10-209, slip op. (U.S. Oct. 31, 2011) (arguing that deficient performance at the preliminary hearing is a paradigmatic example of the type of error that will not, as a general matter, have an "impact on the adjudication of guilt"); see also id. at 14 (showing counsel's concession that the complete deprivation of counsel at the plea bargain stage would be permissible so long as the defendant ultimately pleads not guilty and has a fair trial). Putting it in stark terms, the Michigan Solicitor General argued that "[one is] entitled to effective counsel at every critical stage; however, it is not a Sixth Amendment violation unless it casts doubt on the reliability of the adjudication of guilt." Id. at 15 .

61 Coleman v. Alabama, 399 U.S. 1, 8 (1970) (internal citations omitted).

$62 I d$. at 9.

$63 I d$. 
portunity to challenge defects or weakness in the accusatory instrument as a critical stage even though the appeal arrived at the Court after Coleman had already been found guilty at trial. ${ }^{64}$ Accordingly, the import of challenging the prosecution's charges pretrial must be understood as resting on some consideration independent of the reliability or fairness of the trial, because, after all, the defendant was convicted in Coleman on the very charges that appointed counsel might have challenged as insufficient at a preliminary hearing. ${ }^{65}$ The reasoning in Coleman, then, lends support to the conclusion that the right to counsel serves fairness goals beyond the safeguarding of a fair trial. ${ }^{66}$ Such a view is shared by Bruce Green, who has explained that the right to counsel does more than enhance the reliability of the process, and instead must be recognized as facilitating the "availability of other constitutional and procedural protections afforded criminal defendants." ${ }^{\circ 7}$

The second case that provides substantial support for the view that Strickland's guarantee of fundamental fairness must be liberally construed is Kimmelman v. Morrison. ${ }^{68}$ In Kimmelman, the defendant's trial counsel "failed to file a timely suppression motion" based on violations of the defendant's Fourth Amendment rights, and the prosecution subsequently relied on unsuppressed evidence to secure a conviction. ${ }^{69}$ Justice Brennan, writing for the majority, emphasized that the failure to seek suppression was "not due to strategic decisions," and instead was the product of a "startling ignorance of the law." Notably, there was no dispute that the unsuppressed evidence was entirely reliable. In other words, Kimmelman sought relief for a right to counsel violation based on the failure of his counsel to exclude reliable but unconstitutionally seized evidence. The majority held that inadequacies of this sort on the part of counsel violated the Sixth Amendment. Specifically, the Court reasoned that if there was a rea-

$64 I d$. at 11 (concluding, ultimately, that a remand for harmless error review was appropriate).

65 But see id. at 19-20 (Harlan, J., concurring in part and dissenting in part) (emphasizing that in his view only errors that would taint the fairness of the trial would justify reversal).

66 Although Coleman is a plurality opinion there are five votes for recognizing the preliminary hearing as a critical stage. Id. at 9-10; see also id. at 11-12 (Black, J., concurring) (supplying five votes for the view that a preliminary hearing is a "critical stage" and explaining that the right to counsel applies to all stages of the "criminal prosecution" and not merely those that are important to a vague notion of the "fair trial").

67 Bruce A. Green, Lethal Fiction: The Meaning of "Counsel" in the Sixth Amendment, 78 Iowa L. REV. 433, 440-41 (1993) (footnote omitted).

68477 U.S. 365 (1986).

$69 \quad I d$. at 385 .

$70 \quad I d$. 
sonable probability of success at the suppression hearing, and if success at the suppression hearing would create a reasonable probability that the defendant would not have been convicted, then the right to counsel must be enforced so as to nullify the conviction. ${ }^{71}$

In other words, Kimmelman can fairly be read to stand for the proposition that the right to counsel can be violated if counsel fails to secure the exclusion of reliable evidence of guilt. The right to counsel permits the nullification of a reliable and otherwise fair guilty verdict, a conclusion that strongly bolsters the view that the right to counsel should be understood as requiring a non-instrumental and broad conception of Strickland's promise of fundamental fairness. As the majority explained, "we decline to hold either that the guarantee of effective assistance of counsel belongs solely to the innocent or that it attaches only to matters affecting the determination of actual guilt."72

Notably, however, Justice Powell wrote a concurrence emphasizing that this issue was not actually decided by the Kimmelman decision. Justice Powell wrote for three Justices in order to emphasize that, although interesting, the issue of whether the admission of relevant and reliable evidence can ever violate the right to counsel was not "raised by the parties nor discussed by the various courts involved in this case." ${ }^{73}$ The concurrence concludes that the proper scope of the opinion is limited to deeming such arguments forfeited. And while Justice Powell concluded that it "appears" the majority has accepted this course, he wrote separately to criticize the majority's broad language that tends to suggest that the Court "resolved the broader Strickland issue." ${ }^{\prime 4}$ It is, therefore, plausible to conclude, as Professor Joshua Dressler does, that the "Court does not have a holding squarely resolving" the question of whether the right to counsel permits a court to set aside a reliable verdict predicated, at least in part, on in-

Id. at 389 .

Id. at 380 (emphasis added).

$I d$. at 391 (Powell, J., concurring). In addition to the limitation advocated by Justice Powell, it is worth pointing out that even Kimmelman, perhaps the Court's most robust application of the right to counsel, is trial-centered in its application. The Kimmelman majority emphasized that the right to effective assistance, unlike the Fourth Amendment, is a trial right, and, thus, because the failures of counsel had diminished the defendant's opportunity to receive a full and fair trial, the right to counsel had been violated. Id. at 374 . In other words, Kimmelman can be understood as rejecting a strict innocence or reliability focus but nonetheless reinforcing a trial-oriented right to counsel. Moreover, Kimmelman might be read as reflecting the necessary force of the right to counsel in circumstances where counsel is necessary to protect a defendant against government misconduct that will prejudice the defendant at trial.

$74 \quad$ Id. at 391. 
admissible but reliable evidence. ${ }^{75}$ With few exceptions, however, the reaction to Kimmelman for the past two and a half decades has been to embrace the broad language from the majority opinion; ${ }^{76}$ indeed, lower courts have extrapolated from Kimmelman a general rule that attorney errors will typically justify setting aside reliable and otherwise legally sound convictions. ${ }^{77}$

Accordingly, Kimmelman has important implications for understanding the type of "fundamental fairness" protected by the right to counsel. $^{78}$ This is not to suggest that Kimmelman answers all of the questions. In Kimmelman, the Court recognized that a jury verdict, though reliable, could be tainted by attorney error if there was a reasonable probability of acquittal but for counsel's mistakes. ${ }^{79}$ That is to say, it might be regarded as an unwarranted expansion of Kimmelman to conclude that procedural unfairness that does not call into question the likelihood of the verdict provides a basis for Sixth

75 DRESSLER \& MiCHAELS, supra note 59, at $\$ 4.08$ [c] [i].

76 In Owens v. United States, Judge Posner overruled a line of precedent that had adopted Justice Powell's view of the Strickland test in the suppression context. 387 F.3d 607, 61011 (7th Cir. 2004). Professor Carissa Hessick has observed that scholars "have criticized the $[$ Strickland $]$ prejudice standard" on the theory that "all defendants are entitled to effective representation, even if it would not alter the outcome of trial." Carissa Byrne Hessick, Ineffective Assistance at Sentencing, 50 B.C. L. REV. 1069, 1079-80 (2009) (footnotes omitted). A narrow reading of Strickland, however, undermines the force of Kimmelman and orients Strickland to concerns of truth-seeking, factual innocence, and trial fairness.

77 In Cave v. Singletary, for example, the court acknowledged the propriety of reversing an otherwise valid conviction when defense counsel had misapprehended the meaning of felony murder and proceeded on a capital defense based on this misunderstanding. 971 F.2d 1513, 1518 (11th Cir. 1992). Ultimately, the Court found no prejudice in that case because of the defendant's confessions and overwhelming evidence of guilt; however, the critical point is that the court was willing to recognize that a conviction must, in circumstances of unfairness, be set aside despite the absence of any arguments against its reliability. Id.

78 One is forced to wonder whether the Roberts Court's overt hostility to overturning convictions in the Fourth and Fifth Amendment contexts might have implications for the continued vitality of decisions like Kimmelman. Cf. Berghuis v. Thompkins, 130 S. Ct. 2250 (2010) (upholding the denial of a motion to suppress inculpatory evidence from an interview where the defendant remained silent for the first two hours and forty-five minutes of a three-hour interrogation because such silence did not constitute defendant's assertion of his right to remain silent); Maryland v. Shatzer, 130 S. Ct. 1213 (2010) (holding that defendant's invocation of his Miranda rights did not apply to a subsequent interrogation conducted three years later and consequently those statements could not be suppressed); Herring v. United States, 555 U.S. 135 (2009) (holding that evidence obtained pursuant to an arrest based on a warrant recalled months earlier could not be suppressed where the police had no knowledge that the warrant had been recalled).

79 Kimmelman v. Morrison, 477 U.S. 365, 375 (1986) ("Where defense counsel's failure to litigate a Fourth Amendment claim competently is the principal allegation of ineffectiveness, the defendant must also prove that his Fourth Amendment claim is meritorious and that there is a reasonable probability that the verdict would have been different absent the excludable evidence in order to demonstrate actual prejudice."). 
Amendment relief. Kimmelman, in other words, while undermining centrality of reliability, does not diminish the importance of counsel in preserving a full and fair adversarial trial.

In addition to Kimmelman and Coleman, there is a third line of cases supporting a broad conception of the right to counsel that extends beyond mere fairness at trial, namely, the right to counsel cases that limit police confrontations with the individual. ${ }^{80}$ In Spano v. New York, ${ }^{81}$ the Court suppressed a defendant's confession by holding that it had been obtained in a manner that was sufficiently coercive as to violate due process; however, four Justices concurred to explain that they regarded the post-charge police interrogation of the defendant in the absence of counsel as "an even more important ground [for the] decision." ${ }^{82}$ The concurrence went so far as to postulate that "[d] epriving a person, formally charged with a crime, of counsel during the period prior to trial may be more damaging than denial of counsel during the trial itself." ${ }^{\prime 3}$ About five years later, in Massiah $v$. United States, a majority of the Court embraced the reasoning of the Spano concurrence and held that the right to counsel was violated when law enforcement officers deliberately elicited statements from the defendant after he had been indicted. ${ }^{84}$ The right to counsel, then, protects not against police badgering, which is the focus of the protections enshrined in Miranda $v$. Arizona, ${ }^{85}$ but rather, there is a sense that cases like Massiah reflect a generally "broad understanding of the fair trial interests served by the Sixth Amendment." ${ }^{, 66}$ It is not that the statements obtained without coercion post-charging are

See, e.g., Brewer v. Williams, 430 U.S. 387 (1977) (holding that defendant was denied his constitutional right to counsel where police interrogated him after both the police and defendant agreed he would not answer questions until he conferred with his lawyer); Massiah v. United States, 377 U.S. 201 (1964) (holding that evidence obtained from a radio transmitter planted in defendant's automobile while defendant was out on bail and after defendant had already retained a lawyer could not be used in court).

81360 U.S. 315 (1959)

$82 I d$. at 324 (Douglas, J., concurring).

83 Id. at 325

84 Massiah, 377 U.S. at 206.

85 Miranda v. Arizona, 384 U.S. 436, 445 (1966) (observing that the interrogation cases before the court all "share salient features-incommunicado interrogation of individuals in a police-dominated atmosphere, resulting in self-incriminating statements without full warnings of constitutional rights").

86 Professor Tomkovicz has persuasively argued that the Supreme Court's decision in Fellers v. United States, 540 U.S. 519 (2004) evinces a "broader understanding of the fair-trial interests" served by the right to counsel. Tomkovicz, supra note 35, at 522. These conclusions, however, predate recent Sixth Amendment decisions. See, e.g., Montejo v. Louisiana, 556 U.S. 778 (2009) (permitting police to approach and interrogate a defendant post-attachment of the right to counsel so long as the defendant waives Miranda warnings). 
somehow unreliable and unfit to support a verdict; rather, there is a quasi-professional ethics tone to the Massiah rule that is fitting for a right that enshrines a wide range of fairness protections, not just fairness of a verdict. ${ }^{87}$ In short, it is not just about the fairness of the trial; instead, the concern is with the integrity of the criminal process much more generally - that is, the right to counsel serves the goals of "fair play" and "parity" between defense and prosecution even when there is not yet a trial. ${ }^{88}$ It is a sense of fairness liberated from the outcomes or likely outcomes of the trial. ${ }^{89}$ And if the right to counsel simpliciter protects interests beyond the fairness and reliability of the verdict, then it stands to reason that the right to effective assistance of counsel must enjoy a similarly robust construction..$^{90}$ To be sure, the Supreme Court has only applied the Massiah doctrine as a vehicle for suppressing certain evidence at trial. And in this way, Massiah itself might be understood as announcing a vision of the right to counsel that is thoroughly intertwined with the trial itself. That is to say, one might argue that the Massiah line of cases is simply designed to ensure the fairness and reliability of the trial itself.

Recently, however, the Supreme Court signaled that it was appropriate to regard the Massiah doctrine as substantially divorced from the requirements of a fair trial. In Kansis $v$. Ventris, the Court held that statements obtained by police in violation of Massiah could be used to impeach a defendant. ${ }^{91}$ But the implications of the holding might be considerably broader than the narrow issue of impeachment at trial. If the right to counsel is violated at the time of the police confrontation, then " $[\mathrm{t}]$ he interest protected there is [that of] being free from certain types of governmental exploitation and deception, regardless of whether inculpatory evidence is obtained and used." Ventris suggests that the right to counsel is violated at the moment the officers attempt to elicit statements from a defendant, regardless of whether or not they are successful. But, if the right to counsel can be violated prior to trial in circumstances that do not render the verdict or the trial itself unreliable or unfair, as Ventris

$87 \quad$ See Massiah, 377 U.S. at 206

88 Tomkovicz, supra note 5 , at 40.

89 Halpern, supra note 48, at 143.

90 Just as representation at trial serves as a gateway to a variety of statutory and constitutional rights that are not inherently related to guilt or innocence, pretrial representation provides benefits that are distinct from the fairness of the trial. See Tomkovicz, supra note 5, at 40 .

91 Kansas v. Ventris, 556 U.S. 586, 591-92 (2009) (discussing the Massiah protections of the Sixth Amendment).

92 Gardner, supra note 40, at 422 n.105 (quoting Halpern, supra note 48, at 143). 
suggests, then by extension, the right to effective assistance of counsel might be understood to be triggered and violated even when the trial itself is not rendered unfair. ${ }^{93}$

There are two additional, less developed lines of cases that lend credence to the view that the right to counsel functions to protect procedural fairness distinct from, and even unrelated to, the fairness of trial. First, there is a line of cases recognizing that in the context of the right to effective assistance of counsel for an appeal, the failure to file a timely appeal constitutes an automatic violation of the right to counsel, even if no prejudice can be shown. ${ }^{94}$ This understanding of the right to an effective attorney for the first appeal as of right appears to enjoy support across the lower federal courts, including a panel decision for the Second Circuit joined by Sonia Sotomayor in $2000 .^{95}$ It must be noted, of course, that the right to counsel on appeal is, technically speaking, regarded as a freestanding due process right. ${ }^{96}$ However, in practice, the right to appellate counsel has effectively functioned as an extension of the right to counsel under the Sixth Amendment. In fact, when a court sets out to determine whether the incompetence of appellate counsel amounted to ineffective assistance of counsel, the appropriate inquiry is whether the Strickland test is satisfied. ${ }^{97}$ Indeed, some lower courts apply Strickland to such claims without so much as a mention of the fact that the inquiry is actually one of due process rather than the right to counsel. ${ }^{98}$ It is, therefore, noteworthy that the courts are willing to infer ineffective assistance when the appellate lawyer fails to file a timely appeal regardless of the merits of the appeal in question; such reasoning implies, if only indirectly, that the right to counsel is sufficiently ca-

93 As Gardner had predicted, such a rule suggests that the Massiah cases are "aimed at deterring governmental violations of some substantive interest . . rather than merely protecting rights to procedural fairness by suppressing such evidence once it is obtained." Gardner, supra note 40, at 434. On the other hand, the Ventris decision is concerned, not with the core of the right to counsel, but only the prophylactic protections that inhere from the right under Massiah, and perhaps, the right to counsel proper cannot be violated until the trial, whereas the prophylactic Massiah right can only be violated prior to trial. Cf. Chavez v. Martinez, 538 U.S. 760, 772-73 (2003) (recognizing that the Fifth Amendment's prophylactic protection, Miranda, is only violated when statements are used at trial, but relying on the text of the Fifth Amendment- "in a criminal case"-for this distinction).

94 See, e.g., Rodriquez v. United States, 395 U.S. 327, 329-31 (1969).

95 Hernandez v. United States, 202 F.3d 486 (2d Cir. 2000).

96 Ross v. Moffitt, 417 U.S. 600, 600-01 (1974) (explaining Douglas v. California, 372 U.S. 353 (1963), as a due process rule).

97 See, e.g., Hernandez, 202 F.3d at 489 (using the Strickland test to determine effectiveness of appellate counsel). 
pacious as to protect procedural rights independent of the merits of the defendant's defense or the fairness of his trial. ${ }^{99}$

Finally, and perhaps most revealing is the Padilla $v$. Kentucky decision, which considered the viability of ineffective assistance claims predicated on inadequate advice regarding the collateral consequences of a plea bargain. ${ }^{100}$ In Padilla, the Court stressed that "[t]he importance of accurate legal advice for noncitizens accused of crimes has never been more important" and emphasized that legal advice regarding immigration consequences are "an integral part-indeed, sometimes the most important part" of representation for persons who are considering pleading guilty. ${ }^{101}$ The Court went on to hold that defense counsel has an affirmative obligation to advise his client about the risks of deportation that flow from a plea bargain. ${ }^{102}$ This explicit recognition that something other than the trial, and something other than the criminal consequences, may constitute the most important aspect of appointed counsel's duties, strongly suggests a conception of the right to counsel that is designed to safeguard procedural fairness entirely distinct from the question of guilt, reliability, or trial fairness. That is to say, by suggesting that certain ancillary duties of counsel are equally, if not more, important than the trial itself, Padilla supports a broad construction of the right to counsel. ${ }^{103}$

$* * *$

In sum, there is an established line of cases and scholarship that supports the view that the right to counsel serves goals beyond safeguarding against trial unfairness or verdict unreliability. ${ }^{104}$ As the

99 Gardner, supra note 40, at 401-03 (devoting considerable attention to cases suggesting that governmental intrusions or interference with the lawyer-client relationship justifies relief even where no unfairness to the trial or proceedings ultimately results). If Professor Gardner's reading of these cases is correct, then this would lend additional support to the view that the right to counsel serves ends distinct from the instrumentalist goals of trial fairness and verdict reliability.

100130 S. Ct. 1473, 1486 (2010).

101 Id.

$102 I d$. at 1486

103 The danger with reading Padilla too broadly is that the Court, while recognizing that advice relating to pleas may serve a more important function than representation at trial itself, remanded for consideration of whether the defendant had established Strickland prejudice. Id. at 1478 ("Whether he is entitled to relief depends on whether he has been prejudiced, a matter that we do not address.").

104 See Halpern, supra note 48, at 133-36 (distinguishing between the Sixth Amendment's "instrumental" purposes (i.e., meant to avoid "actual adversary prejudice to the accused") and its "intrinsic" purposes (i.e., meant to vindicate "respect for intrinsic integrity of the accused")). Notably, Halpern had no occasion to contemplate the scope of the right to 
Court has elaborated in the context of the right to counsel of choice, " $[i] \mathrm{t}$ is true enough that the purpose of the rights set forth in that Amendment is to ensure a fair trial; but it does not follow that the rights can be disregarded so long as the trial is, on the whole, fair." 105

\section{B. Signs of a Trial-Centered Approach to Fairness}

In contrast to the broad non-trial-centered approach to Strickland discussed above, some scholars have argued that the right to counsel is nothing more than a basic check on the fairness of the verdict or the trial itself. The appointment of counsel, so envisioned, is merely a means of facilitating the accuracy of the verdict. ${ }^{106}$ As Professor Akhil Amar has summarized this viewpoint, "innocence protection and truth-seeking are, or should be, central" to our understanding of the proper scope of the right to counsel. ${ }^{107}$ The right to counsel, in other words, is provided "to enforce the law's letter and spirit, not to evade them." ${ }^{108}$ Such a view historically has found substantial support in the Supreme Court's Sixth Amendment case law. ${ }^{109}$

effective assistance of counsel as a vehicle for what he calls the "intrinsic" ends because when his impressive paper was published, Strickland $v$. Washington had not yet been decided.

105 United States v. Gonzalez-Lopez, 548 U.S. 140, 145 (2006).

106 Halpern, supra note 48, at 135. The oral arguments in Lafler v. Cooper and Missouri v. Frye contain arguments from the State party in both cases that endorse this narrow construction of the right to counsel. The Michigan Solicitor General, for example, framed his entire argument in Cooper around the principle that "in order to prove a Sixth Amendment violation, you have to demonstrate unreliability of the adjudicatory process." Transcript of Oral Argument at 5, Lafler v. Cooper, No. 10-209, slip op. (Oct. 31, 2011); id. at 7 (arguing that only when the "reliability of the adjudicatory process" is undermined can the prejudice prong be satisfied). Under this view, there is a right to effective assistance only as to the guilty plea, and, by contrast, the right to counsel cannot be violated by advice leading one to exercise his trial right so long as the representation at trial was constitutionally adequate. Id. at 13 (during argument Justice Scalia explained that when a defendant pleads guilty he deprives himself of the "24-karat test of fairness," but when the defendant gets a trial he cannot complain insofar as "you can't do any better than that").

107 AMAR, supra note 16, at 138, 140-41 (examining "the innocence-protecting spirit" of the right to counsel and explaining that "without counsel [a defendant] runs an undue risk of being convicted, even if wholly innocent").

108 Id. at 141

109 Like the right to effective assistance of counsel, the due process right to have exculpatory evidence turned over by the prosecution has a prejudice standard that tends to be oriented towards reliability and innocence. Leslie Kuhn Thayer, The Exclusive Control Requirement: Striking Another Blow to the Brady Doctrine, 2011 WIS. L. REv. 1027, 1049 (2011) ("In formulating Brady's materiality standard, Bagley explicitly relied on and adopted the Strickland test for prejudice."); see United States v. Bagley, 473 U.S. 667, 682-83 (1985) (defining materiality by reference to the Strickland prejudice standard); see also Corinna Barrett Lain, Accuracy Where it Matters: Brady v. Maryland in the Plea Bargaining Context, 80 WASH. U. L.Q. 1, 39 n.183 (2002) ("Interestingly, the test announced in Strickland for es- 
First, it is not insignificant that the two cases most famously associated with the Court's recognition of an affirmative right to counsel as a fundamental right, Gideon v. Wainwright ${ }^{110}$ and Powell v. Alabama, ${ }^{111}$ both provide symbolic, if not conclusive, support for the conclusion that the right to counsel is primarily an instrument of ensuring a fair trial, and in particular that innocent persons are not convicted. In Gideon, the Court explained that the defendant "who is too poor to hire a lawyer, cannot be assured a fair trial unless counsel is provided for him."112 Moreover, the Court emphasized that the right to counsel was consistent with a long line of "procedural and substantive safeguards designed to assure fair trials before impartial tribunals." 113 Donald Dripps has signaled his approval for such a reading of Gideon by emphasizing that the strongest support for the right to counsel is the Court's recognition that such a right is "fundamental to a fair trial." ${ }^{114}$ Likewise, in Powell, the Court's insistence on the trial-based nature of the protection is explicit, as the Court explains that without a lawyer an indigent defendant "faces the danger of conviction because he does not know how to establish his innocence." $" 115$

tablishing prejudice was, in turn, based on one of three materiality standards employed in a previous Brady case, United States v. Agurs, 427 U.S. 97 (1976).”). Notably, in the context of prosecutorial disclosure, the Court has held that pretrial disclosures (at the time of plea) are not necessary insofar as they do not serve the goal of protecting the innocent. United States v. Ruiz, 536 U.S. 622, 631 (2002). Given the doctrinal link between Brady claims and Strickland claims, it seemed likely that relief under Strickland would be limited to instances where the defendant could show that counsel's errors undermined confidence in the verdict. Cf. Douglass, supra note 3, at 581-82 (encouraging an innocence focused conception of the Brady right).

287 U.S. 45 (1932).

Gideon, 372 U.S. at 344.

Id.

Dripps, supra note 21, at 266.

115 Powell, 287 U.S. at 69. Notably, however, there is language in Powell suggesting that the appointment of counsel is important for other reasons that do not seem linked to the accuracy or fairness of the trial. For example, the Court suggests that the assistance of counsel would allow a defendant to know whether he was facing invalid charges or a defective indictment. Id. (explaining that the layman "is incapable, generally, of determining for himself whether the indictment is good or bad"). Moreover, the issue presented in Gideon and Powell was only whether a trial could comport with fundamental fairness in the absence of counsel; the question of whether the right to counsel was similarly fundamental for preserving non-trial fairness was not at issue. As the Court explained when it extended the right to counsel to sentencing in Mempa v. Ray, "[T] here was no occasion in Gideon to enumerate the various stages in a criminal proceeding at which counsel was required," and the best way to understand Gideon is to recognize the force of the right to counsel at all stages "where substantial rights of a criminal accused may be affected." 389 U.S. 128, 134 (1967); see also Halpern, supra note 48, at 135 (characterizing Gideon and 
The understanding of the right to counsel as a mere means of facilitating the ends of innocence protection, truth, and reliability is supported, in varying degrees, by other Supreme Court decisions. ${ }^{116}$ The Court's decision in Nix $v$. Whiteside is particularly significant in this regard. ${ }^{117}$ In Nix, the defendant was charged with murder based on a marijuana transaction gone bad, and the only issue was whether the defendant had a viable claim of self defense. Defense counsel believed that Nix was embellishing the facts in support of his self defense claim and explained their response as follows:

[W] e could not allow him to [testify falsely] because that would be perjury, and as officers of the court we would be suborning perjury if we allowed him to do it; ... I advised him that if he did do that it would be my duty to advise the Court of what he was doing and that I felt he was committing perjury; also, that I probably would be allowed to attempt to impeach that particular testimony. ${ }^{11}$

Setting aside defense counsel's threat to impeach his own client, which the Court did not address, ${ }^{119}$ the Court considered defense counsel's comments to his client to be proper under the governing rules of professional responsibility, and on this basis held that the defendant could not make out a colorable claim of ineffective assistance of counsel. ${ }^{120}$ The Court's deficient performance analysis is of the most practical relevance to lower courts and practicing lawyers, but its holding regarding the prejudice prong is more conceptually interesting. As to deficient performance, the Court emphasized the general need for loyalty to the client, but explained that the duty is necessarily "limited to legitimate, lawful conduct compatible with the very na-

Powell as expressing an instrumentalist interest in the fairness of the proceeding, and not simply the innocence of the defendant). 116 In United States v. Cronic, the Court explained that the "underlying purpose" of the right
to counsel is the preservation of "truth" in the criminal process. 466 U.S. 648, 655 (1984).

117 Nix v. Whiteside, 475 U.S. 157 (1986).

$118 I d$. at 161 . The Court summarized these events as follows: Until shortly before trial, Whiteside consistently stated to Robinson that he had not actually seen a gun, but that he was convinced that Love had a gun in his hand. About a week before trial, during preparation for direct examination, Whiteside for the first time told Robinson ... that he had seen something "metallic" in Love's hand. Id. at 160-61.

119 In light of the Court's willingness to ground its holding in the ethical rules and the ethically proper response of counsel to the threat of perjury, it is interesting to note that defense counsel was surely incorrect in his assumption that it would be ethically proper for him to impeach his own client on the witness stand, and yet the Court does not discuss the impact of unethical threat.

120 Notably, the federal habeas statute in effect at the time required the federal courts to defer to the state court's findings of fact, which included a finding that if the defendant had testified that he thought he had seen a gun it would have been perjury. 28 U.S.C. $\S 2254(d)(2006)$. 
ture of a trial as a search for truth." ${ }^{121}$ In other words, the obligations of a lawyer extend beyond the client and protect the integrity of the judicial process. Even a lawyer who utterly fails to advance his client's interests may be acting in a manner sanctioned by the Sixth Amendment when counsel is facilitating the discovery of truth to the extent permitted by the rules of professional responsibility. ${ }^{122}$

As to prejudice, the Court effectively holds that Strickland's requirement of a "reasonable probability" of a different outcome implies that the different outcome would be sufficiently just and reliable. ${ }^{123}$ The Court has subsequently described the rule of Nix by observing that " $[\mathrm{o}]$ bviously, had the [defendant] presented false testimony to the jury, there might have been a reasonable probability that the jury would not have returned a verdict of guilty," ${ }^{124}$ and yet the Nix Court concluded that "it does not follow that [the defendant] was prejudiced." 125 The implication is that only certain alternative outcomes count for purposes of Strickland prejudice. ${ }^{126}$ The mere fact that a defendant may have prevailed, but for the actions of defense counsel, is not necessarily a basis for Strickland relief when the underlying guilt determination is fundamentally fair and factually reliable. The Court explained that because the defendant's "truthful testimony could not have prejudiced the result of his trial," there can be no claim of ineffective assistance of counsel, and thus the logic of Nix is not easily reconciled with the notion that the right to counsel is infringed even when innocence is not in doubt. ${ }^{127}$ The model of fair-

121 Nix, 475 U.S. at 166.

122 Compliance with the ethical rules entirely insulates an attorney from a claim of deficient performance. Id. at 175; McClure v. Thompson, 323 F.3d 1233, 1248 (9th Cir. 2003) (holding that if counsel was acting "to preserve the lives of the children rather than to protect the interests of his client, the ethical rule requiring an attorney to act to prevent a crime means that such an action" does not constitute deficient performance by counsel).

123 Nix, 475 U.S. at $175-76$.

124 Lockhart v. Fretwell, 506 U.S. 364, 370 (1993); see also Nix, 475 U.S. at 186-87 (Blackmun, J., concurring) ("To the extent that Whiteside's claim rests on the assertion that he would have been acquitted had he been able to testify falsely, Whiteside claims a right the law simply does not recognize.").

125 Nix, 475 U.S. at 176.

126 Jeffries \& Stuntz, supra note 39, at 686-88 (observing that Whiteside stands for the notion that prejudice cannot be established by attorney errors that "do not affect the factual reliability of the determination of guilt" and noting that "Whiteside and Kimmelman are hard to reconcile").

127 Nix, 475 U.S. at 176 (Brennan, J., concurring). 
ness protection envisioned by Nix seems more closely associated with a protection for the innocent against wrongful convictions. ${ }^{128}$

The narrow vision of the right to counsel suggested by Nix was substantially confirmed eight years later in Lockhart $v$. Fretwell, ${ }^{129}$ when the Court held that defense counsel's "failure to make an objection in a state criminal sentencing proceeding-an objection that would have been supported by a decision which subsequently was overruled" did not amount to a denial of effective assistance. ${ }^{130}$ In this case, unlike Nix, the question of counsel's deficient performance was readily satisfied, but the Court again held that there was no prejudice. As in Nix, the Court suggested that errors of counsel resulting in unfavorable outcomes only justify relief when the "reliability of the trial process" is called into question by the errors of counsel. ${ }^{131}$ The outcome may have been different had counsel performed competently, but because the proceeding was reliable and otherwise fair, the Court held that the relief was unavailable. ${ }^{132}$ Emphasizing this narrow construction of the right to counsel, the Fretwell majority explained: "the right to the effective assistance of counsel is recognized not for its own sake... [rather] [a]bsent some effect of challenged conduct on the reliability of the trial process, the Sixth Amendment guarantee is generally not implicated." "133

Accordingly, Fretwell and Nix are readily harmonized with Akhil Amar's view that the right to counsel is fundamentally a "truth-

128 Kimmelman was decided only a few months after Nix, and yet the Kimmelman decision does not so much as cite Nix. Kimmelman v. Morrison, 477 U.S. 365 (1986). The two cases are difficult to reconcile.

129506 U.S. 364 (1993)

$130 I d$. at 366 . Counsel had failed to object to an aggravating factor (pecuniary gain) that was part of the predicate felony for purposes of felony murder. Id. at 367 . Under the circuit court law at the time, this double-counting of the pecuniary aggravator constituted legal error and made the death sentence unlawful. Id. However, by the time the case was reviewed on federal habeas grounds, the double-counting of the aggravator was no longer legal error. See Lowenfield v. Phelps, 484 U.S. 231, 233 (1988).

131 Fretwell, 506 U.S. at 369.

132 In Fretwell, the Court explicitly observes that "as a matter of law, counsel's conduct... cannot establish the prejudice required for relief under the second strand of Strickland inquiry." 506 U.S. at 370 (internal citations omitted).

133 Id. at 369 (quoting United States v. Cronic, 466 U.S. 648, 658 (1984)) (emphasis added); see also Strickland v. Washington, 466 U.S. 668, 696 (1984) ("In every case the court should be concerned with whether ... the result of the particular proceeding is unreliable ...."). Notably, in Williams v. Taylor, 529 U.S. 362, 397 (2000), the Court rejected an overly broad reading of Fretwell by the Virginia Supreme Court. In Williams, however, the state court had refused relief even when the defendant had shown that the result of his sentencing proceeding was factually unreliable-that is to say, Fretwell is not so broad as to insulate from reversal most attorney errors that undermine the factual reliability of a jury proceeding. See Jeffries \& Stuntz, supra note 39 , at $686-87$. 
seeking architecture;" ${ }^{134}$ but Fretwell and Nix are not alone in this regard. For example, in Gerstein v. Pugh, the Court held that there was no right to counsel, and, thus, implicitly no right to effective assistance, at a probable cause determination because the absence of counsel at such a proceeding would not ultimately "impair [one's] defense on the merits." 135 Thus, Gerstein stands for the proposition that the scope of the right to counsel is limited to safeguarding rights that relate to the merits of one's case, and counsel is not constitutionally required as a means of protecting procedures that are tangential to the underlying strength of the prosecution's case. Emphasizing this point, Justice Alito recently authored a concurrence explaining that "defense," as the term is used in the Sixth Amendment, refers to "defense at trial, not defense in relation to other objectives that may be important to the accused." ${ }^{136}$ Under this view, pretrial representation is required only when the "pretrial events may so prejudice the outcome of the defendant's prosecution that, as a practical matter, the defendant must be represented at those events in order to enjoy genuinely effective assistance at trial." ${ }^{137}$

Other lines of Supreme Court authority further entrenched the view that the right to counsel is not available to protect interests unrelated to the trial itself. For example, in United States v. Cronic, the Court explained that the "core purpose of the counsel guarantee was to assure 'Assistance' at trial" and it elaborated that the right to counsel's "ultimate objective" was to ensure that the "guilty be convicted and the innocent go free." 138 Even more interesting, William Stuntz

134 AMAR, supra note 16 , at 141 .

135 Gerstein v. Pugh, 420 U.S. 103, 122 (1975).

136 Rothgery v. Gillespie Cnty., 554 U.S. 191, 216 (2008) (Alito, J., concurring).

137 Id. at 217. This concurrence is not merely of idle interest; it was joined by three Justices. Justice Thomas wrote a dissent expressing his narrower view of the Sixth Amendment, and Chief Justice Roberts provided a separate, but most cagey concurrence predicated on stare decisis. There were, then, prior to Lafler and Frye, five potential votes for explicitly refusing to extend the right to effective assistance of counsel to pretrial appointments that do not have direct bearing on the outcome of the trial.

138 Cronic, 466 U.S. at 654-55 (internal citations omitted). This conclusion is further bolstered by the Court's approach in cases involving government intrusions or interference with the lawyer-client relationship. When the trial itself is tainted, for example, by refusing the defense an opportunity to meet with his client, then no independent prejudice is required. But when there is merely a government intrusion or interference with the lawyer-client relationship unrelated to the trial, prejudice is required. Compare United States v. Morrison, 449 U.S. 361 (1981) (encouraging defendant to fire her attorney requires prejudice), and Weatherford v. Bursey, 429 U.S. 545 (1977) (intruding on private lawyerclient meetings requires prejudice), with United States v. Gonzalez-Lopez, 548 U.S. 140 (2006) (denying defendant counsel of choice does not require prejudice), Geders v. United States, 425 U.S. 80 (1976) (precluding an attorney from meeting with his client during an overnight break does not require prejudice), Herring v. New York, 422 U.S. 
went so far as to say that the defining limitations on the right to counsel, such as the attachment doctrine, are justified primarily by a desire to preserve the right to counsel's preoccupation with truth seeking and fair trials. ${ }^{139}$ Stuntz has candidly observed that "lawyers retard evidence gathering" and, thus, the seemingly formalistic limitations on the right to counsel prior to trial are designed as means of "counteracting lawyers' efforts to shield guilty clients." 140 In other words, the attachment doctrine has developed so as to limit the ability of the right to counsel to foil the truth eliciting "staple of criminal investigation." Stated more directly, limiting the attachment of the right to counsel until after the formal criminal proceedings have commenced "makes no sense if one sees the right to counsel as aiming to benefit defendants as a whole, or even poor defendants as a whole. It does make sense if the right aims to benefit innocent defendants primarily." ${ }^{42}$ The attachment rule itself, in other words, supports the conclusion that the right to counsel is oriented toward truth and trial fairness alone. ${ }^{143}$

853 (1975) (prohibiting a defense lawyer from providing a closing argument does not require prejudice), and Brooks v. Tennessee, 406 U.S. 605 (1972) (requiring a defendant to testify first does not require prejudice).

139 An illustrative example of an attachment case is United States v. Hayes, 231 F.3d 663 (9th Cir. 2000), where the prosecution conducted depositions of material witnesses prior to the defendant's indictment. Id. at 667-68. The defendant was required to attend the depositions and counsel was appointed so that the defendant would have an opportunity to cross-examine the witnesses. During this period, the prosecution, without the presence of counsel, surreptitiously elicited incriminating statements from the defendant. Id. The Ninth Circuit held that although the defendant had been appointed counsel, and although the facts closely resembled those of Massiah, because the right to counsel had not attached, there was no Sixth Amendment violation. Id.

140 William J. Stuntz, Lawyers, Deception, and Evidence Gathering, 79 VA. L. REV. 1903, 1906-07 (1993).

$141 \quad I d$. at 1921.

142 Id. at 1947. Professor Stuntz further concludes that: Defense lawyers thus play a complicated and not altogether happy role in criminal litigation. They are needed to ensure adequate separation of innocent from guilty defendants at trial, and in order to serve that function they must enter the picture soon enough to prepare a case for trial (and to enter into plea bargains). Yet the earlier lawyers become part of the process, the greater the likelihood that their participation will be a relative benefit to the least deserving parties. Id. at 1955 .

143 Just as the attachment limitation undercuts would-be efforts by counsel to obfuscate for the client, the critical stage doctrine's limitation as to when counsel must be present likely serves a similar function. See Metzger, supra note 12, at 1679-80 (arguing that presentence interviews should be regarded as a critical stage because the presence of counsel will help prevent the defendant from "blurt[ing] out information that increases his sentence"). But see United States v. King, 559 F.3d 810, 814 (8th Cir. 2009) ("[N]o court has found the Sixth Amendment right to counsel applies to routine presentence interviews." (internal quotation marks omitted)). 
Finally, the Court's recent decision in Premo v. Moore, addressing ineffective assistance of counsel at the plea bargaining stage, also seemed to foreshadow a narrow conception of the right to pretrial effective assistance. ${ }^{144}$ In Premo, the defendant argued that his counsel had provided constitutionally inadequate representation by failing to suppress certain confessions before engaging in plea bargaining. ${ }^{145}$ In assessing the appropriate standard for Strickland prejudice in the plea context, the Ninth Circuit Court of Appeals concluded that the defendant was prejudiced because, but for counsel's errors in failing to suppress a confession, there was a "reasonable possibility that [the defendant] would have obtained a better plea agreement." er words, the "different outcome" required by Strickland would be satisfied so long as a better plea offer was reasonably likely, even if there was no argument that the accuracy of the result or the guilt determination were impinged. Relying on the deferential framework for review under the Anti-Terrorism and Effective Death Penalty Act, the Court, without dissent, announced that the only clearly established standard for prejudice in this context requires the defendant to show "a reasonable probability that, but for counsel's errors, he would not have pleaded guilty and would have insisted on going to trial." ${ }^{147}$ Notably, in order to show a reasonable probability that one would have proceeded to trial, the defendant must show that it was reasonable to proceed to trial-that is, that he had a reasonable chance of acquittal at trial. ${ }^{148}$ In other words, the Court insisted on a prejudice analysis for pretrial errors that required a trial-based showing of injury. ${ }^{149}$

\footnotetext{
$144 \quad 131$ S. Ct. 733 (2011).

145 Id. at 738.

146 Id. at 745 .

147 Id. at 743 (quoting Hill v. Lockhart, 474 U.S. 52, 59 (1985)); see also Premo, 131 S. Ct. at 746 (Ginsburg, J., concurring) (internal quotation marks omitted).

148 See Hill, 474 U.S. at 59 ("[W] here the alleged error of counsel is a failure to investigate or discover potentially exculpatory evidence, the determination whether the error 'prejudiced' the defendant by causing him to plead guilty rather than go to trial will depend on the likelihood that discovery of the evidence would have led counsel to change his recommendation as to the plea. This assessment, in turn, will depend in large part on a prediction whether the evidence likely would have changed the outcome of a trial."); LAFAVE ET AL., supra note 17, at $\$ 21.3$ (b) n.46 (““[T] he prejudice prong' ... is 'unduly burdensome' because it is 'next to impossible for a defendant with no transcript and a hypothetical jury to prove an effect on the outcome of a hypothetical trial ....').

149 To be sure, the analysis in Premo is of limited predictive utility insofar as the Court was primarily applying the onerous standard for relief under the habeas corpus statute for state prisoners, 28 U.S.C. $§ 2254(\mathrm{~d})$, and in this vein the decision's holding was limited to discussing what is the "clearly established" law on this question. Nonetheless, the analysis seems to foreshadow a narrow view of the right to counsel. Interestingly, the U.S. Solici-
} 
The deficient performance analysis in Premo is similarly indicative of a trial-centered conception of the right to counsel. The Court reasoned that "at different stages of the case" the deference to trial counsel errors "must be measured in different ways," and thus "when there is no extended formal record" like that from a trial, "and no factual history to show how the charges have played out at trial [this] works against the party alleging inadequate assistance."150 In other words, the Premo case expressly enunciates a right to counsel framework that is overtly hostile and unaccommodating to claims of pretrial ineffective assistance divorced from the strength of one's likely success at trial. There is a higher standard for alleging errors of counsel in the rough and tumble context of pretrial bargaining, hearings, and litigation.

$$
* * *
$$

In short, at least until recently, there has been substantial support for the view that the Warren Court's willingness to pursue "social objectives extrinsic to reliable outcomes" has long since passed, ${ }^{151}$ and that the right to counsel has entered an era of increasing hostility to conviction-nullifying rules that serve freestanding goals.

\section{FORESHADOWING A NON-TRIAL ORIENTATION FOR THE RIGHT TO COUNSEL: THE FRYE AND LAFLER DECISIONS}

In March of 2012 the Supreme Court decided the Lafler and Frye cases, the aggregate effect of which is to drastically, if not definitively, announce a Sixth Amendment framework that is fundamentally divorced from fair trial concerns. In Missouri v. Frye, defense counsel failed to communicate a plea offer of ninety days in jail to Frye, and the plea offer expired. ${ }^{152}$ Later, Frye pled guilty without a plea agreement and was sentenced to three years in prison. ${ }^{153}$ Explaining that it "is well settled that the right to the effective assistance of counsel applies to certain steps before trial," ${ }^{154}$ the Court held that "it is in-

tor General's office has not shied away from relying on Premo as defining the constitutional standard in this context. See Transcript of Oral Argument at 26, Missouri v. Frye, No. 10-444 slip op. (Oct. 31, 2011).

150 Premo, 131 S. Ct. at 745 ("The added uncertainty that results when there is no extended, formal record and no actual history to show how the charges have played out at trial works against the party alleging inadequate assistance.").

Halpern, supra note 48, at 167-68.

Missouri v. Frye, No. 10-444, slip op. at 2 (U.S. Mar. 21, 2012).

$I d$.

Missouri v. Frye, No. 10-444, slip op. at 3 (U.S. Mar. 21, 2012). 
sufficient to simply point to the guarantee of a fair trial as a backstop that inoculates any errors in the pretrial process." ${ }^{155}$ Accordingly, the Court held that the errors of counsel in causing his client to miss out on a favorable plea can amount to a Strickland deprivation. Similarly, in Lafler $v$. Cooper, the Court held that deficient performance resulting in a defendant's refusal to accept a favorable plea offer could amount to a right to counsel violation even when the defendant was ultimately convicted and sentenced through a full and fair trial. Specifically, the Court in Lafler expressly rejected the suggestion that an "otherwise fair trial remedies errors not occurring at the trial itself." The Court expressly held that the Sixth Amendment is "not designed simply to protect the trial" and reasoned that errors by counsel resulting in a sentence that was more than three times as severe as the plea offer could be unconstitutional even if the trial was full and fair. ${ }^{15}$

Taken together these two decisions substantially eviscerate the view that the right to counsel is primarily a protection against unfair trials. And the significance of this development was not missed on the four dissenting Justices. Writing the dissents in both Missouri $v$. Frye and Lafler $v$. Cooper, Justice Scalia accused the majority of establishing "a whole new field of constitutionalized criminal procedure." 158 Of course, determining whether these decisions reflect a dramatic break from the previous Sixth Amendment jurisprudence depends on the extent to which one understands the Court's previous decisions as having limited the right to counsel to those circumstances where the fairness of the trial was undermined. For Justice Scalia, the case law discussed in Part II of this Article leads to the unmistakable conclusion that the purpose of the right to counsel was to "ensure a fair trial" or a "fair adjudication of guilt and punishment." 159

Regardless of whether these cases were a product of the prior Sixth Amendment precedent or not, the holding that a full and fair trial does not suffice to undermine an otherwise colorable claim of ineffective assistance opens the door to a wide range of new Sixth Amendment claims. More precisely, the scope of the right to pretrial effective assistance is substantially broader, or at least more certain,

Missouri v. Frye, No. 10-444, slip op. at 7 (U.S. Mar. 21, 2012).

Lafler v. Cooper, No. 10-209, slip op. at 7 (U.S. Mar. 21, 2012).

Lafler v. Cooper, No. 10-209, slip op. at 6-7 (U.S. Mar. 21, 2012).

Lafler v. Cooper, No. 10-209, slip op. at 1 (U.S. Mar. 21, 2012) (Scalia, J., dissenting).

Lafler v. Cooper, No. 10-209, slip op. at 4 (U.S. Mar. 21, 2012) (Scalia, J., dissenting) (describing the majority opinions as "a vast departure from our past cases"). 
after Lafler and Frye. The practical implications of this robust, nontrial-centered understanding of Strickland are elaborated below.

\section{UNDERSTANDING THE RIGHT: CONSEQUENCES OF A BROAD CONCEPTION OF RIGHT TO COUNSEL}

Because many pretrial procedural rights are, at best, tenuously related to the reliability of the verdict or the fairness of the trial, the extent to which the right to counsel extends beyond trial-related concerns will oftentimes be determinative in considering whether a wide range of constitutional and statutory rights are protected by the right to effective assistance of counsel. This section explores the implications of a broad understanding of the right to pretrial effective assistance. Specifically, it moves through four illustrative, though not exhaustive, examples of pretrial procedural (as opposed to factual) errors by counsel and assesses the likelihood of Strickland relief under a broad rather than a narrow construction of the right to counsel.

To be sure, the Court's decisions in Frye and Lafler lend substantial support for the view that the pretrial errors of counsel, even if they do not undermine the fairness of the trial, can amount to a Sixth Amendment violation. It remains to be seen, however, whether the Court will insist on a showing that the errors of counsel contributed to a less favorable outcome, in terms of convictions or sentencing for the defendant. ${ }^{160}$ As illustrated below, the extent to which the Court limits the scope of pretrial effective assistance to errors impacting one's conviction or sentence will ultimately determine whether the right to pretrial effective assistance is a valuable right in the context of claims unrelated to plea bargaining.

160 In both Lafler and Frye the defendant argued that he received a more severe sentence because of the errors of counsel. See Missouri v. Frye, No. 10-444, slip op. at 11 (recognizing that in order to "establish prejudice" a defendant generally must show a reasonable probability that the end result of the criminal process would have been more favorable in terms of the verdict or the sentence). 


\section{A. Petit Jury Selection ${ }^{161}$}

The defense and prosecution in every jurisdiction are permitted a certain number of peremptory challenges. ${ }^{162}$ These challenges permit the party to strike a juror whom they fear is disposed to view the case unfavorably to their side, but for whom there is an insufficient basis to support a challenge for cause. ${ }^{163}$ The use of peremptory challenges, then, is not designed to remedy any actual bias, and the right to use a peremptory challenge is "not of constitutional dimension." The use of a peremptory challenge, however, is subject to important constitutional limits. In Batson v. Kentucky, the Court held that a prosecutor's use of peremptory challenges was constrained by equal protection principles such that the discriminatory use of peremptory challenges was unconstitutional. ${ }^{165}$ If, however, a defendant fails to raise a Batson violation prior to the empanelment of the jury, the claim is almost universally deemed to have been forfeited or waived. ${ }^{166}$

The crucial question for purposes of understanding more generally the scope of the right to counsel protections is whether a defense

161 Although the discussion here is limited to petit jury selection, in particular Batson claims, the analysis of failures by counsel to challenge the jury venire under, for example, Taylor v. Louisiana, 419 U.S. 522 (1975), would raise nearly identical concerns if Strickland is narrowly conceived. See also Vasquez v. Hillery, 474 U.S. 254 (1986) (addressing constitutional challenges to an improperly selected grand jury); Sanders v. Norris, 529 F.3d 787, 791 (8th Cir. 2008) (concluding that counsel's deficient performance as to voir dire questioning cannot give rise to Strickland prejudice when there was no demonstrated juror bias on the part of the empanelled jurors).

162 FED. R. CRIM. P. 24 (providing the prosecution with six and the defense ten peremptory challenges in non-capital cases); Busby v. State, 894 So. 2d 88, 98 (Fla. 2004) ("Today, every state provides peremptory challenges to both parties in criminal and civil cases." (internal citation omitted)).

163 Swain v. Alabama, 380 U.S. 202, 220 (1965) ("While challenges for cause permit rejection of jurors on a narrowly specified, provable and legally cognizable basis of partiality, the peremptory permits rejection for a real or imagined partiality that is less easily designated or demonstrable." (internal citation omitted)).

164 Ross v. Oklahoma, 487 U.S. 81, 88 (1988).

165 Batson v. Kentucky, 476 U.S. 79, 86 (1986) ("Purposeful racial discrimination in selection of the venire violates a defendant's right to equal protection .....").

166 As a leading treatise has explained, "Perhaps no standard governing the scope of appellate review is more frequently applied than the rule that an error not raised and preserved at trial will not be considered on appeal." 7 CRIM. Proc. $\$ 27.5$ (c) (3d ed.) (citing State v. Ford, 306 Mont. 517, 39 P.3d 108 (2001) (Batson claim waived when counsel failed to raise objection until the jury was empanelled and the venire was dismissed)); see also Christopher L. Ekman, Batson Challenges in State and Federal Courts in Alabama: A Refresher of Recent Decisions, 72 ALA. LAW. 46, 51 (2011). ("From the standpoint of a party raising a Batson challenge, it is critical to voice that objection contemporaneously during the jury selection process and before trial begins, or else it may be waived."); Sawyer v. Sw. Airlines Co., 145 F. App'x 238, 240-41 (10th Cir. 2005) (recognizing that a failure to raise Batson results in a waiver); 9B FED. PRAC. \& PROC. CIV. $\$ 2472$ (3d ed.), n.8. 
lawyer's failure to timely raise a valid equal protection claim in the context of jury selection can serve as the basis for nullifying an otherwise reliable verdict. Given the nature of the Batson right's protections, the question of whether relief is available when counsel fails to vindicate the right is likely dependent on whether a narrow or broad construction of Strickland is applied. That is to say, a reading of Frye and Lafler that stresses a conception of the right to counsel that is divorced from a fair trial is of the utmost importance to understanding the extent to which Batson provides a cognizable basis for right to counsel relief.

The first critical step in this analysis is recognizing that the nature of the Batson right is such that the failure of counsel to vindicate this right does not inherently undermine the reliability or fairness of the verdict. The Batson case itself involved a prosecutor's attempt to remove all of the African American jurors from the venire so as to leave an African American defendant with an all-white jury, but subsequent decisions have abandoned reliance on the significance of the common racial identity between the defendant and the excused jurors. ${ }^{167}$ Moreover, the Court has even held that Batson serves as a limitation on the use of peremptories by the defense. ${ }^{168}$ In light of these adaptations, Batson is now primarily a "symbolic," public "cynicism"-avoiding and "public confidence"-enhancing, right; ${ }^{169}$ it serves ends independent of "protect[ing] individual defendants" $"$ and the fairness of the trial. ${ }^{171}$ Batson is now generally regarded as a third-party protection for the jurors and the judicial system more than a protection for the

167 See Powers v. Ohio, 499 U.S. 400, 402 (1991) (holding that "a criminal defendant may object to race-based exclusions of jurors effected through peremptory challenges whether or not the defendant and the excluded jurors share the same race").

168 See Georgia v. McCollum, 505 U.S. 42, 55 (1992) ("[A] defendant's discriminatory exercise of a peremptory challenge is a violation of equal protection ....").

169 Id. at 49

170 Powers, 499 U.S. at 406; see id. ("In Batson, we spoke of the harm caused when a defendant is tried by a tribunal from which members of his own race have been excluded. But we did not limit our discussion in Batson to that one aspect of the harm caused by the violation. Batson was designed to serve multiple ends, only one of which was to protect individual defendants from discrimination in the selection of jurors." (internal citation and quotation marks omitted)).

171 In addressing the retroactivity of Batson, the Court, in Allen v. Hardy, held that it was not appropriate to apply it retroactively because under then governing law the question was whether "a new constitutional principle is designed to enhance the accuracy of criminal trials." 478 U.S. 255, 259 (1986) (per curiam) (internal citation omitted). In other words, the Court held that truth-protecting function of the trial is not necessarily enhanced by the Batson rule. 
defendant himself. ${ }^{172}$ Indeed, rather than holding that a fair trial was not possible without the Batson protection, the Court, at times, has been forced to defend the Batson right as narrowly compatible with the fair trial right itself. ${ }^{173}$ That is to say, the Batson right is not primarily, or perhaps at all, about enhancing impartiality or reliability, because such concerns, the Court has explained, are adequately safeguarded in this context through challenges for cause. ${ }^{174}$

Given the purpose of the Batson protection, divorced as it is from trial fairness, the viability of a claim of ineffective assistance of counsel in this context is contingent on the acceptance of a narrow or a broad conception of the fairness protection underlying the right to counsel. If the right to counsel serves as a broad promise of fairness such that the right is violated whenever counsel's errors deprive the defendant of a material procedural protection, then the failure to timely raise a Batson claim justifies reversal. ${ }^{175}$ Alternatively, if the right to counsel is construed narrowly so as to require some unfairness at the trial stage, or some unreliability of the verdict, then a guilty verdict issued by an unbiased jury following a fair trial would not justify relief.

Construing the right to counsel broadly, in Lafler the Court held that a conviction resulting from a fair trial must be set aside when errors by counsel caused the defendant to forego a favorable plea offer. Consider the potential application of Lafler $v$. Cooper in this context. By analogy, a defendant who receives a fair trial and is convicted by

172 For example, one scholar has remarked that: "The fact is that Batson only makes analytical sense if one recognizes that it has shifted the primary focus from the rights of the litigants to the rights of prospective jurors." Kenneth J. Melilli, Batson in Practice: What We Have Learned About Batson and Peremptory Challenges, 71 Notre DAME L. REv. 447, 453 (1996) (footnote omitted) (emphasis added). Another scholar's defense of Batson makes no effort to justify the doctrine in terms of the defendant's right to a fair trial, or the need for a reliable verdict; instead the focus is on enforcing an ethical standard on lawyers. See Laura I. Appleman, Reports of Batson's Death Have Been Greatly Exaggerated: How the Batson Doctrine Enforces a Normative Framework of Legal Ethics, 78 TEMP. L. REv. 607, 609-10 (2005). For a contrary perspective, see Jeffries \& Stuntz, supra note 39, at 717 (explaining their view that, at least prior to the most recent line of Batson decisions, the rule could be understood as "designed to secure just outcomes" but recognizing that the rule may not promote accuracy of the verdict in "any particular case").

173 In holding that a defendant could violate Batson, the Court explained that "[i]t is an affront to justice to argue that a fair trial includes the right to discriminate" during jury selection. Georgia v. McCollum, 505 U.S. 42, 57 (1992) (explaining that if the cost of a fair trial requires such discrimination, then the cost is "too high").

174 McCollum, 505 U.S. at 59 (rejecting "the view that assumptions of partiality based on race provide a legitimate basis for disqualifying a person as an impartial juror").

175 See also Hamilton v. Alabama, 368 U.S. 52, 54 (1961) (suggesting that the right to counsel is necessary to protect any claim or defense that would otherwise be permanently forfeited or lost). 
an unbiased jury is still entitled to reversal for a Batson error if there is a reasonable probability that but for the errors of counsel the defendant would have been tried by a different jury. ${ }^{176}$ In other words, there must be a reasonable probability that the defendant would have prevailed on a timely Batson motion - that is, a reasonable probability of a different outcome at the relevant proceeding. ${ }^{177}$ Relief in these circumstances is entirely independent of a claim that the trial would have been different with the proper jury. ${ }^{178}$

By contrast, under a narrow construction of Strickland, like that urged by the state in Frye and Lafler, a court would not find a Sixth Amendment violation when counsel fails to timely raise Batson viola-

176 See Davis v. Sec'y for Dep't of Corr., 341 F.3d 1310, 1316 (11th Cir. 2003) (holding that the prisoner established a reasonable probability that state courts would have reversed his conviction had his ineffective trial counsel preserved his Batson claim for review on appeal, and, thus, granting federal habeas relief); Gov't of Virgin Islands v. Forte, 865 F.2d 59, 65 (3d Cir. 1989) (" $[\mathrm{I}] \mathrm{f}$ there was a Sixth Amendment violation the remedy will be to give Forte what he should have gotten in the first place, an explanation from the prosecutor as to why she used her peremptory challenges and a ruling by the court on whether Forte has established that there was purposeful discrimination. Of course, if the court concludes that there was a Fourteenth Amendment violation his conviction and sentence will be vacated.”); see, e.g., Davidson v. Gengler, 852 F. Supp. 782, 783 (W.D. Wis. 1994) (holding that in the Batson context, the "test for determining prejudice on an ineffective assistance claim is not whether the outcome of the trial would have been different, but ... whether the results of [the] jury selection process would have been different had a Batson objection been made.").

177 This view seems to best capture the spirit of Batson's protections insofar as Batson errors are structural. See, e.g., Eagle v. Linahan, 279 F.3d 926, 943 (11th Cir. 2001) ("Where, as here, appellate counsel fails to raise a [Batson] claim on appeal that is so obviously valid that any competent lawyer would have raised it, no further evidence is needed to determine whether counsel was ineffective for not having done so."); Tankleff v. Senkowski, 135 F.3d 235, 248 (2d Cir. 1998) (holding that Batson violations are structural error); Davis, 341 F.3d at 1317 (11th Cir. 2003) (noting that most circuits appear to regard Batson as structural error); Ex parte Yelder, 575 So. 2d 137, 138-39 (Ala. 1991) (concluding that a presumption of prejudice, as with cases of actual conflicts of interest by counsel, is appropriate when defense counsel fails to raise a colorable Batson claim).

178 The circuits have split on the related question of whether defense counsel's failure to take any action when a juror is exposed to prejudicial information pretrial-e.g., a peremptory strike, or even confirming that the juror will decide the case based on the evidence presented-can give rise to relief under the Sixth Amendment even if the juror ultimately was not prejudiced. Compare Fields v. Brown, 503 F.3d 755, 775-76 (9th Cir. 2007) (holding that defendant was not prejudiced by counsel's deficient questioning during voir dire where habeas evidentiary hearing revealed that jurors who served were not actually biased), and Sanders v. Norris, 529 F.3d 787, 790-94 (8th Cir. 2008) (same), with Breakiron v. Horn, 642 F.3d 126, 146 (3rd Cir. 2011) ("The proper inquiry under Strickland is not whether [the juror was] actually rendered [] biased or partial, but whether there is a reasonable probability that a juror who had not been exposed to that statement would have voted to acquit ..."); $i d$. (holding that the prisoner "was not required to show that [the juror] was actually influenced by [the] statement, but had only to show a reasonable probability that any given juror would have been"). 
tions. ${ }^{179}$ A state appellate court in Missouri summarized this view when it rejected an attorney's improper and incomplete Batson objection as establishing ineffective assistance: "Post-conviction relief for ineffective assistance of counsel is limited to errors which prejudiced the movant by denying him a fair trial. The failure to properly preserve Batson claims for review on appeal is not...cognizable." ${ }^{180}$ Likewise, the Louisiana Supreme Court addressed a claim of ineffective assistance in this context by observing that, "Batson [does] not go "to the heart of the truthfinding function," and therefore, it "cannot be said that the violation of such rule renders the trial unfair and the verdict suspect." tory exercise of peremptory challenges" is not primarily a safeguard of the defendant's own rights, ${ }^{182}$ a series of Eighth Circuit decisions has also denied right to counsel relief in these circumstances. In Young v. Bowersox, for example, the court rejected the defendant's argument that the nature of Batson claims as structural error ought to trump the Strickland requirement of prejudice. ${ }^{183}$ The court held that an error of counsel in failing to raise a Batson claim did not warrant Strickland relief "if the error had no effect on the judgment." 184 The court explained that the focus of Strickland's prejudice inquiry must be "on the outcome of the individual trial," and in the absence of a showing of bias on the part of the jury, the removal of minorities, or

179 See, e.g., Lafler v. Cooper, No. 10-209, slip op. at 6 (U.S. Mar. 21, 2012) (noting the government's argument that the right to counsel should be strictly limited so as to protect nothing more than the "fair trial").

180 State v. Link, 965 S.W.2d 906, 912 (Mo. Ct. App. 1998) (citing the state's post-conviction rule, Rule 29.15, which allows for relief when a defendant's conviction violates the "laws of this state or the constitution of the United States"); see also Strong v. State, 263 S.W.3d 636, 647 (Mo. 2008) (en banc) (finding an absence of prejudice because the defendant's allegation of Batson error, taken as true, does not establish "a reasonable probability that [defendant] would have been found not guilty").

181 State v. Snyder, 750 So. 2d 832, 842 (La. 1999) (internal citations omitted); see also Strong v. State, 263 S.W.3d 636 (Mo. 2008) (holding that failure to raise religious objections did not constitute a Batson violation); Smith v. State, 877 So. 2d 369 (Miss. 2004) (holding that theoretical and statistical conjecture of racial prejudice in jury selection was not sufficient to claim ineffective assistance under Batson); Wardley v. State, 760 So. 2d 774 (Miss. Ct. App. 1999) (holding that prejudice could not be satisfied because defendant could not prove reasonable probability of a different verdict in the absence of Batson violation); Batiste v. State, 888 S.W.2d 9 (Tex. Crim. App. 1994) (holding that prejudice must be shown from a failure to make a Batson objection); Gregory G. Sarno, Annotation, Adequacy of Defense Counsel's Representation of Criminal Client Regarding Right to and Incidents of Jury Trial, 3 A.L.R. 4th 601, §5[b] (1981) (compiling cases raising ineffective assistance of counsel claims based on counsel's failure to raise a Batson violation)

182 Davis v. Sec'y for Dep't. of Corr., 341 F.3d 1310, 1317 (11th Cir. 2003).

183 161 F.3d 1159, 1160-61 (8th Cir. 1998).

$184 I d$. at 1161 (internal citations omitted). 
women, or religious groups cannot give rise to a right to counsel deprivation. ${ }^{185}$ Even more revealing, just last year the Illinois Supreme Court held that when a defendant receives ineffective assistance of counsel that results in a biased juror actually being seated on the jury, he is still not entitled to relief unless he can demonstrate a specific injury to his trial rights, for example, that the evidence at trial was substantially lacking such that a fair jury would not have found him "guilty beyond a reasonable doubt." 186

In short, as the Batson right has become less about protecting the defendant from a biased jury or an unreliable verdict and more about protecting the third-party rights of the jurors themselves, the failure to raise such a claim does not justify relief under a trial-oriented conception of the right to counsel. ${ }^{187}$ Simply put, a narrow conception of Strickland cannot countenance relief when trial counsel fails to raise a valid Batson claim; as the decisions just mentioned note, the defendant is not deprived of his constitutionally protected right to a fair trial when counsel negligently, gratuitously, or even intentionally fails to raise a valid Batson claim.

But much has changed since each of these cases applying Strickland to the jury selection process were decided. The judicial obsession with a showing of innocence or unfairness of the verdict ${ }^{188}$ is in stark contrast with Lafler's holding that a fair trial does not cure constitutionally ineffective pretrial representation. ${ }^{189}$ A missed plea offer, no more than a botched voir dire, may not impede the ultimate reliability of the proceeding, but to limit the right to counsel to trial-

185 Id. (quoting Wright v. Nix, 928 F.2d 270, 274 (8th Cir. 1991)); see also Teague v. Scott, 60 F.3d 1167, 1172 (5th Cir. 1995) (“[A]ttorney[s'] actions during voir dire are considered to be a matter of trial strategy. A decision regarding trial tactics cannot be the basis for a claim of ineffective assistance of counsel unless counsel's tactics are shown to be so ill chosen that it permeates the entire trial with obvious unfairness."); Scott v. State, 183 S.W.3d 244, 248 (Mo. Ct. App. 2005) ("It is well-settled that post-conviction relief based on ineffective assistance of counsel is limited to errors which prejudiced a movant by denying that movant the right to a fair trial.").

186 People v. Manning, 948 N.E.2d 542, 548 (Ill. 2011).

187 Many of the Batson cases, even the cases clarifying that Batson provides a defendant with third-party standing to challenge the equal protection injury to the jury, continue to insist that a Batson violation causes a "criminal defendant cognizable injury." Powers v. Ohio, 499 U.S. 400, 411 (1991). But the "injury" allegedly suffered by the defendant is reputational harm to the "integrity of the judicial process," and the injury to a juror in being removed on improper grounds has been described as a defect in the "fairness of a criminal proceeding." Id. (internal citations omitted).

188 See, e.g., Hall v. State, 663 S.W.2d 926, 927-28 (Ark. 1984) (Adkisson, C.J., dissenting) ("A procedural rule must not take precedence over an uncontested adjudication of guilt."). 
type fairness is to fail to "comprehend the full scope of Sixth Amendment protections." 190

\section{B. Speedy Trial Claims}

Professor Akhil Amar once wrote that it is the right to counsel that "makes real" the guarantees of the speedy trial protection. ${ }^{191}$ The very essence of the right to counsel is its ability to assist defendants with this sort of "technical procedural law: where to file, with what words, before whom, and so on." 192 As with a Batson claim, however, the failure of counsel to raise a viable speedy trial claim may not result in an unfair trial or an unreliable verdict.

On the one hand, ineffective assistance resulting in the deprivation of a speedy trial claim would seem to have a strong claim to Strickland relief. To be sure, one could establish that but for the errors of counsel the "result" or the "outcome" would be different in that the defendant would not have been convicted. ${ }^{193}$ The ultimate outcome of the case was, as in Lafler and Frye, less favorable to the defendant because of the errors of counsel. ${ }^{194}$ But such relief is not likely, or at least not obviously available under the narrow, trial-centered construction of Strickland. ${ }^{195}$

Notably, the speedy trial protection is not primarily a safeguard on the fairness or reliability of the trial. In discussing the constitutional

190 Lafler v. Cooper, No. 10-209, slip op. at 10 (U.S. Mar. 21, 2012). Notably, however, even in Frye and Lafler, there was a reasonable probability that the errors of counsel deprived the defendant of a more favorable outcome-not a fair trial, but a reduced sentence. By contrast, there is no probability of a more favorable ultimate outcome when Batson is violated. The defendant could show a reasonable probability of a different jury-that is, a different voir dire. But it remains unclear whether Lafler and Frye require relief in these circumstances.

191 AMAR, supra note 16, at 139.

192 Id

193 Johnson v. Zerbst, 304 U.S. 458, 465 (1938) ("The purpose of the constitutional guaranty of a right to counsel is to protect an accused from conviction resulting from his own ignorance of his legal and constitutional rights ...."); see also Williams v. Taylor, 529 U.S. 362, 396 (2000) (endorsing a relatively outcome-centered approach to Strickland).

194 In particular, Frye and Lafler suggest that for purposes of establishing a reasonable probability of a different outcome, the outcome need not be a fair trial, or any other particular outcome. The failure to vindicate one's speedy trial rights certainly implicates the outcome-i.e., the viability of the conviction. Missouri v. Frye, No. 10-444, slip op. at 7 (U.S. Mar. 21, 2012); Lafler v. Cooper, No. 10-209, slip op. at 7 (U.S. Mar. 21, 2012).

195 Professors Jeffries and Stuntz would seemingly endorse this conclusion as a natural consequence of the narrow conception of the right to counsel they urged the Court to adopt more than two decades ago. See Jeffries \& Stuntz, supra note 39, at 723 (explaining that so understood, counsel is merely an "aid to accurate results" and not an "end in itself" and observing that effective assistance ought to be a "tool for reaching right results"). 
right to a speedy trial, the Court has observed that prolonged delays may "impair the ability of an accused" to obtain a fair trial, ${ }^{196}$ and in Barker v. Wingo, the Court set forth four factors for determining whether a speedy trial harm has occurred, one of which is "prejudice" to the defendant. ${ }^{197}$ But the Court has also emphasized that the speedy trial right is different from most other constitutional rights in that it actually protects "a societal interest in providing a speedy trial which exists separate from, and at times in opposition to, the interests of the accused." ${ }^{198}$ That is to say, the speedy trial right, though theoretically justified in part by the defendant's fair trial concerns, is unique insofar as a "deprivation of the right may work to the accused's advantage." Certainly, if a defendant's right to counsel is understood as contingent upon a showing of trial unfairness or unreliability, then speedy trial claims that actually "work to the accused's advantage" could not be the source of relief. ${ }^{200}$ Doggett $v$. United States confirms this conclusion. ${ }^{201}$

In Doggett, the Court found that a lengthy delay between Doggett's indictment and trial constituted a speedy trial violation even though Doggett did not know about the indictment and appeared to have suffered no particularized prejudice because of the delay. ${ }^{202}$ Justice O'Connor dissented in Doggett in order to reject the majority's view that the mere "possibility of prejudice" is sufficient to warrant speedy trial relief and argued that a defendant should be required to make "a showing of actual prejudice." ${ }^{203}$ Doggett is significant, therefore, because it expressly held that "affirmative proof of particularized prejudice is not essential to every speedy trial claim." ${ }^{204}$

Because a deprivation of the speedy trial right does not require actual injury to the integrity or the reliability of the defendant's trial, under a trial-centered conception of Strickland, a defendant's right to

196 United States v. Ewell, 383 U.S. 116, 120 (1966).

197 The four factors are: "length of delay," "reason" for the delay, "whether and how the defendant asserts [the] right," and "prejudice." Barker v. Wingo, 407 U.S. 514, 530 (1972).

198 Id. at 519

199 Id. at 521.

200 Id. at 521 (noting that a "difference between the right to speedy trial and the accused's other constitutional rights is that deprivation of the right may work to the accused's advantage").

201505 U.S. 647 (1992).

$202 I d$. at 670 (Thomas, J., dissenting) ("[T] he Court compels dismissal of the charges against Doggett not because he was harmed in any way by the delay between his indictment and arrest, but simply because the Government's efforts to catch him are found wanting." (footnote omitted)).

203 Id. at 659 (O'Connor, J., dissenting).

204 Id. at 655. 
counsel may not be violated when his attorney fails to seek dismissal of a case pretrial based on a viable speedy trial claim. As one state court judge has explained this view, "an attorney's failure to raise a speedy trial claim is not ineffective assistance of counsel because the procedural rules setting the time for trial do not impinge on the integrity" of a guilty verdict or plea. ${ }^{205}$ In other words, a successful speedy trial claim does not involve a showing that the defendant was "denied a fair determination of his guilt" and, thus, there is no colorable basis for establishing Strickland prejudice. ${ }^{206}$

To date, however, most lower courts that have addressed the issue hold that the failure of counsel to raise a valid speedy trial claim that would have resulted in dismissal justifies reversing a guilty verdict. ${ }^{207}$ For example, the Indiana Court of Appeals has explicitly held that a defendant is denied his constitutional right to effective assistance of counsel when his counsel fails to secure a defendant's discharge

205 Hall v. State, 663 S.W.2d 926, 927 (Ark. 1984) (Adkisson, C.J., dissenting).

$206 I d$. at 927-28. Notably, Justice Adkisson's opinion was issued just months prior to the Strickland decision. It appears, however, that at the time of the decision Arkansas was applying a very similar standard, requiring a failure by counsel that prejudiced the defendant. Id.

207 My research has not revealed a single claim in which a federal defendant has obtained the reversal of a conviction based on a claim of ineffective assistance of counsel predicated on a failure of counsel to raise a claim under the Speedy Trial Act. There are a substantial number of cases that reason that, even if the time limits of the Act were violated, the failure of counsel to raise the issue did not prejudice the defendant insofar as it is within the discretion to dismiss the case without prejudice. See, e.g., Bramlett v. United States, 405 F. App'x 363, 368 (11th Cir. 2010) (noting that because dismissal without prejudice would have been the appropriate remedy, "a competent attorney . . . reasonably could have decided that filing a motion to dismiss on speedy trial grounds would have only delayed further the resolution of the charges"); Chambliss v. United States, 384 F. App'x 897 (11th Cir. 2010) ("We need not address whether petitioner's trial counsel provided constitutionally deficient performance by failing to move for dismissal of the indictment because we conclude that petitioner did not suffer prejudice. If counsel had moved to dismiss the indictment, the district court would have granted a dismissal without prejudice because of the serious nature of the charges and because the delay did not harm petitioner's ability to present a defense."); Burrus v. Gonzalez, 97 F. App'x 803 (9th Cir. 2004) (considering the application of an analogous state speedy trial act); United States v. Jackson, 22 F. App'x 396, 398 (6th Cir. 2001) (“[H]e has not demonstrated a reasonable probability that the district court would have dismissed the indictment with prejudice." (internal citations omitted)). This is a somewhat troubling trend. It is the speedy trial safeguard that ensures that the anxiety and dangers of pretrial detention are mitigated to the greatest extent possible, and it is the right to counsel that is regarded as the guardian of the right to a speedy trial. AMAR, supra note 16, at 139. If the right to counsel cannot be enforced when counsel fails to raise viable claims of trial delay, then the harms of the trial delay are amplified rather than mitigated by the services of counsel. See Bramlett, 405 F. App'x at 368 (explaining that " $[w]$ here the crime charged is serious, the [district] court should dismiss [with prejudice] only for a correspondingly severe delay" (internal citations omitted)). 
through the filing of a timely and valid motion to dismiss on speedy trial grounds. ${ }^{208}$ Other courts have also recognized the availability of relief in this context, ${ }^{209}$ and such a result is entirely consistent with a broad understanding of the fairness protections embodied by the Strickland right. To be sure, if a narrow vision of the right to pretrial effective assistance emerged as the law of the land-if cases like Premo v. Moore ${ }^{210}$ were understood as defining the contours of the Strickland right, then lower courts would be substantially hostile to nullifying a reliable verdict based on a failure by counsel to litigate a speedy trial claim. ${ }^{211}$ Stated more directly, the Court's speedy trial jurisprudence

208 Pearson v. State, 619 N.E.2d 590, 591-92 (Ind. Ct. App. 1993); see also Maples v. Stegall, 427 F.3d 1020 (6th Cir. 2005) (holding that defendant was prejudiced when he relied on counsel's advice that a guilty plea would preserve his speedy trial claim); Smith v. Lockhart, 923 F.2d 1314, 1319 (8th Cir. 1991) (assessing whether a proceeding was a critical stage and determining that it was, based in part on the fact that counsel could have raised a due process claim based on the State's delay in charging him, and reasoning that such a "motion obviously had the ability to influence the outcome of the proceedings" as necessary for the critical stage analysis, because "if it were granted there would be no trial").

209 The author readily concedes that there are currently very few cases addressing the interaction of the constitutional right to counsel and the right to a speedy trial. This is substantially explained by the fact that relief under the Sixth Amendment for a speedy trial violation is extremely rare. Cf. Anthony G. Amsterdam, Speedy Criminal Trial: Rights and Remedies, 27 STAN. L. REV. 525, 543 (1975) ("[D] ismissal [with prejudice] as a remedy has the sole effect of making judges almost universally prefer the disease."). Courts will often deny ineffective assistance of counsel claims in this context by summarily recognizing that there is no deficient performance because the speedy trial right was not violated. But just as not all prosecutors will comply with Batson, and not all defense lawyers will understand the governing Fourth Amendment law, on occasion a lawyer will misapprehend or miscalculate the application of the speedy trial right and in the process deprive his client of the right to effective assistance, i.e., dismissal with prejudice of the charges. The prospect of such an error warrants attention for its own sake. More importantly, the speedy trial right serves as an important conceptual means of teasing out the contours of pretrial effective assistance of counsel regardless of the urgency of the issue from a litigation standpoint.

210 In Premo, the Court stressed that prejudice could only be shown if counsel's failures gave rise to a reasonable probability that but for counsel's errors the defendant would have had a reasonable chance of succeeding at trial. Premo v. Moore, 131 S. Ct. 733, 744 (2011). Such a standard is, at the very least, hostile to an approach to Strickland that recognizes violations of the right to counsel entirely independent of the strength of one's case at trial. However, Premo was decided on habeas review under 28 U.S.C. § 2254, and the merely held that there was no clearly established federal law, as required by statute, as to whether a non-trial related conception of prejudice was sufficient for purposes of Strickland. Premo v. Moore, 131 S. Ct. 733, 745 (2011) (holding that the clearly established prejudice standard in the plea context "was established in Hill, which held that a defendant who enters a plea agreement must show a reasonable probability that, but for counsel's errors, he would not have pleaded guilty and would have insisted on going to trial").

211 LAFAVE ET AL., supra note 17, at $\$ 11.10$ (d) (describing Fretwell as a limitation on relief in circumstances constituting a windfall). To be sure, the Court's decisions in Frye and Lafler lend substantial support for the view that the pretrial errors of counsel, even if they do 
has made it clear that the deprivation of this right need not involve prejudice to the defendant's fair trial, and, as a practical matter, vindicating this right generally requires competent counsel. Consequently, a trial-focused notion of the right to counsel threatens a dead end for the speedy trial right. ${ }^{212}$

Fortunately, however, the broad conception of the right to counsel enunciated in Lafler and Frye seems entirely consistent with permitting relief when counsel fails to properly raise a viable speedy trial claim. In rejecting the assertion that a fair trial precludes an ineffective assistance of counsel claim relating to a missed plea offer, the Court explained that "the question is not the fairness or reliability of the trial but the fairness and regularity of the processes that preceded it." 213 So long as the defendant can show a "reasonable probability that, but for counsel's unprofessional errors, the result of the proceeding would have been different," then relief is permitted. ${ }^{214}$ In the context of speedy trial claims, a defendant simply must show a reasonable probability that the case would have been dismissed with the competent advice from counsel. ${ }^{215}$ Accordingly, the new era of pretrial effective assistance law ushered in by Frye and Lafler seems to re-

not undermine the fairness of the trial, can amount to a Sixth Amendment violation. It remains to be seen, however, whether the Court will insist on a showing that the errors of counsel contributed to a less favorable outcome, in terms of convictions or sentencing for the defendant, a question that will be of significant import for a range of pretrial ineffective assistance of counsel claims unrelated to plea bargaining.

212 Somewhat related to instances where counsel fails to dismiss a case for speedy trial violations are instances where counsel fails to take advantage of pressing a case to trial or plea when there is a favorable prosecutor on the case. Imagine, for example, that unnecessary delays by defense counsel result in a new, more aggressive prosecutor taking over the case. Such delays could certainly impact the degree of charges or the length of the sentence, but the errors of defense counsel do not undermine the integrity of the trial itself, and certainly do not cast doubt on the verdict's reliability.

213 Lafler v. Cooper, No. 10-209, slip op. at 10 (U.S. Mar. 21, 2012).

214 Lafler v. Cooper, No. 10-209, slip op. at 4 (U.S. Mar. 21, 2012) (internal citation omitted).

215 During oral argument in Frye, Justice Breyer suggested that certain instances of ineffective assistance of counsel may warrant a heightened standard of prejudice. Transcript of Oral Argument at 16-17, 40, Missouri v. Frye, No. 10-444 slip op. (Oct. 31, 2011). The speedy trial claim is a strong candidate for such a limitation because it does present a realistic opportunity for a defense windfall. If defense counsel realizes that he has a reasonable speedy trial claim, he may forego raising it, try his defense at trial, and if the defendant is found guilty, notify appellate counsel of the missed speedy trial claim. Under such circumstances a speedy trial claim that was only colorable but not certain at the time of trial, might lead to definite relief under Strickland. That is to say, it might be a good strategy to forego such a claim if all that is required for post-trial relief is a showing that the claim was viable-i.e., a reasonable probability (less than a preponderance of the evidence) that the claim would have succeeded at trial. Determining the proper remedy for ineffective assistance that causes a defendant to miss out on a claim that would have required dismissal with prejudice is similarly unresolved. 
quires relief in circumstances where the errors of counsel resulted in the defendant missing an opportunity to have his case dismissed on speedy trial grounds.

\section{Challenges to Pretrial Detention}

Understanding the right to counsel in the context of issues relating to pretrial detention presents a particularly complicated example of the potential implications of a broad conception of the right to effective assistance. On the one hand, it is generally assumed, and with good reason, that pretrial detention impedes the fairness of the trial, but on the other hand, the injury to the accuracy or fairness of the trial is often difficult to assess in a particular case through ex post litigation following a conviction. ${ }^{216}$ That is to say, unlike the speedy trial and jury selection rights, it seems that ineffective assistance in the pretrial detention context is assumed to affect the fairness of the trial itself, but the application of Strickland to this context is anything but well established.

It seems probable that in the wake of developments regarding pretrial ineffective assistance, including the broadening conception of these rights through Frye and Lafler, pretrial detention may soon serve as a critical flashpoint in the fight over the proper scope of pretrial effective assistance. Representation relating to pretrial detention is at the critical intersection between rights that seem unrelated to the trial itself, and procedures that may impact, to a varying extent, the trial proceedings and the ultimate fairness of the verdict. As an initial matter, most lower courts seem to assume with little discussion that a bail hearing or detention proceeding is not a critical stage requiring the appointment of counsel. ${ }^{217}$ Indeed, a previous study found that "only eight states and the District of Columbia guarantee that an accused has the assistance of counsel" at this stage. ${ }^{218}$ It is es-

216 Addressing the problem of ex post inquiries more generally, Donald Dripps has called for replacing the post-trial Strickland inquiry with an "ex ante inquiry into whether the defense is institutionally equipped to litigate as effectively as the prosecution." Dripps, supra note 21, at 243 ("It is all but ludicrous to ask a reviewing court to assess a record made by counsel to determine how counsel erred.").

217 United States v. Hooker, 418 F. Supp. 476, 479 (M.D. Pa. 1976) (holding a bail reduction hearing is not a "critical stage" because pretrial detention does not "impair defense on the merits"); $i d$. (explaining that even if bail hearing was a pretrial detention, the illegal pretrial detention does not taint the conviction so as to justify post-trial relief) (citing Frisbie v. Collins, 342 U.S. 519, 523 (1952)).

218 Douglas L. Colbert, Thirty-Five Years After Gideon: The Illusory Right to Counsel at Bail Proceedings, 1998 U. ILL. L. REV. 1, 8-9 (1998) [hereinafter Colbert, The Illusory Right]; see also Douglas L. Colbert et al., Do Attorneys Really Matter? The Empirical and Legal Case for The 
timated that "one out of three incarcerated defendants waits more than two weeks following arrest before speaking with court-assigned counsel." ${ }^{\prime 19}$ Summarizing practices across the country, one group of commentators has provided the following narrative:

It has become common for state court judges to preside over pretrial release hearings of lower-income people without counsel present. Hearings are perfunctory. They move swiftly, aided by video jail broadcasts, which make it unnecessary even to transport arrestees to the local courtroom. In many jurisdictions, a prosecuting attorney is present and recommends bail, thus stacking the odds even more against an accused. Under these circumstances, many defendants choose to remain silent, while others speak and make inculpatory statements, even as they try to minimize their culpability. ${ }^{220}$

For its part, the Supreme Court has concluded that an initial probable cause determination is not a critical stage requiring counsel; ${ }^{221}$ it has seemingly reserved the question of whether an initial appearance is ever a critical stage, ${ }^{222}$ and it has not squarely addressed the issue of whether pretrial detention litigation might, standing alone, trigger the right to appointed counsel. Recent decisions strongly suggest, however, that a majority of the Court does not re-

Right of Counsel at Bail, 23 CARdOzo L. Rev. 1719, 1719 (2002) [hereinafter Colbert, Empirical and Legal Case] ("Contrary to common belief, our legal system does not guarantee a lawyer to every person whose freedom is at stake. Instead, the indigent accused usually stands alone, without counsel to protect his liberty when first appearing at a bail hearing. Most states do not consider the right to counsel to apply until a later stage of a criminal proceeding-days, weeks or months after the pretrial release determination.").

219 Colbert, The Illusory Right, supra note 218, at 3 n.6 (internal citation omitted). This problem should only arise in state cases because Federal Rule of Criminal Procedure 44(a) requires the appointment of counsel at the initial appearance. FED. R. CRIM. P. 44(a) ("A defendant who is unable to obtain counsel is entitled to have counsel appointed to represent the defendant at every stage of the proceeding from initial appearance through appeal, unless the defendant waives this right.").

220 Colbert, Empirical and Legal Case, supra note 218, at 1726.

221 The Court has explained that "[b] ecause of its limited function and its nonadversary character, the probable cause determination is not a 'critical stage' in the prosecution that would require appointed counsel.” Gerstein v. Pugh, 420 U.S. 103, 122 (1975). A recent article has deftly summarized the relationship between the Gerstein hearing and the state practices regarding pretrial release:

In Gerstein v. Pugh, the Court ruled that states were not required to provide an attorney for indigent defendants at their initial court appearance when judicial officers made a probable cause determination and invited states to experiment with procedural practices that combined bail hearings with probable cause determinations. Most local systems eagerly embraced the opportunity. They concluded that since the United States Supreme Court did not require attorneys at the probable cause stage, lawyers were not mandated for pretrial release determinations.

Colbert, Empirical and Legal Case, supra note 218, at 1726. 
gard the detention hearing as a critical stage. For example, in Rothgery v. Gillespie the Court addressed, to a limited extent, the right to counsel's application at an initial appearance-the stage of the proceedings when most defendants first appear and seek release on bail. The most notable feature of the Court's decision was the considerable trouble the Court went through in order to distinguish between the technical "attachment" of the right to counsel and the actual right to appointed counsel. As to the former, the Court explained that the right to counsel attaches at an initial judicial appearance where the defendant is arraigned on informal charges and "restrictions on the accused's liberty" are used to facilitate the eventual prosecution. $^{223}$ But having clarified that the right technically attached at the point of an initial appearance when bail might first be obtained, the Court explicitly cautioned against "the mistake of merging the attachment question (whether formal judicial proceedings have begun) with the distinct 'critical stage' question (whether counsel must be present ...)." ${ }^{224}$ Instead of capitalizing on an opportune moment to clarify that the right to appointed counsel applies to one's first opportunity to seek pretrial release, the Court went some distance in the opposite direction by clarifying that mere technical attachment and the requirement of appointment (and effective assistance) are not equivalent. ${ }^{225}$

Moreover, Justice Alito, writing for himself, Chief Justice Roberts, and Justice Scalia, explained that "I join the Court's [Rothgery] opinion because I do not understand it to hold that a defendant is entitled to the assistance of appointed counsel as soon as his Sixth

$223 \quad I d$. at $207-08$.

$224 I d$. at 211-12.

225 In a footnote, the Court explained that it did not "here purport to set out the scope of an individual's postattachment right to the presence of counsel." Id. at 212 n.15. However, the Court repeatedly discusses with approval the approach of most jurisdictions that is to appoint counsel "before, at, or just after the initial appearance." Id. at 204 (emphasis added). If appointment after the initial appearance does not run afoul of the right to counsel, then by extension ineffective assistance at this proceeding does not violate the right to counsel. Cf. Pennsylvania v. Finley, 481 U.S. 551 (1987) (recognizing that because there is no right to counsel for collateral proceedings, there is also no constitutional right to effective assistance of counsel in these proceedings); Coleman v. Thompson, 501 U.S. 722 (1991) (refusing to extend a right to effective assistance of counsel to proceedings for which there is no constitutional right to counsel). Perhaps, however, the failure to appoint counsel (or the ineffective assistance of counsel) at an initial appearance could, at the very least, serve as a basis for overcoming a procedural default if certain defenses were forfeited or waived at the initial appearance. See, e.g., Martinez v. Ryan, No. 10-1001, slip op. at 5 (U.S. Mar. 20, 2012) (recognizing for the first time that ineffective assistance of counsel may serve as may serve as cause to excuse a procedural default even when there is no constitutional right to counsel). 
Amendment right attaches." ${ }^{226}$ Justice Alito wrote separately in order to emphasize that the right to appointed counsel pretrial is only required as "necessary to guarantee the defendant effective assistance at trial" and to explain that, in his view, the Sixth Amendment's right to counsel for one's "defence" limits the scope of counsel's constitutional duties to "defense at trial, not defense in relation to other objectives that may be important to the accused." ${ }^{227}$ Speaking with even more clarity as to the scope of the right to counsel, Justice Thomas observed that "we have never suggested that the accused's right to the assistance of counsel 'for his defence' entails a right to use counsel as a sword to contest pretrial detention." 228

Consistent with these opinions, the emerging consensus among lower courts, prior to Lafler and Frye, was that the bail hearing was not a critical stage requiring competent representation. ${ }^{229}$ But, such a conclusion assumes away the essence of the critical stage analysis, which, at bottom, is a practical question about whether the absence of counsel at a particular proceeding meaningfully diminishes a defendant's right to a fair criminal process. ${ }^{230}$ That is to say, even under a narrow, pre-Frye and pre-Lafler, conception of the right to counsel, the critical stage analysis requires careful attention to the practical impact of detention hearings on the fairness of one's trial. In view of

226 Rothgery, 554 U.S. at 213-14 (Alito, J., concurring).

227 Id. at 216-17 (citing United States v. Gouveia, 467 U.S. 180, 190 (1984)).

228 Rothgery, 554 U.S. at 235 (Thomas, J., dissenting) (citing Gouveia, 467 U.S. at 190).

229 There do not appear to be any decisions squarely holding that there is a federal constitutional right to counsel at a bail hearing, but it may be too early to describe the lower court decisions to the contrary as forming a consensus. In truth, there appear to be only a handful of courts that have taken up the issue. See United States v. Hooker, $418 \mathrm{~F}$. Supp. 476, 479 (M.D. Pa. 1976) ("A bail reduction hearing is not a 'critical stage' of the proceedings ....”); see also Fenner v. State, 846 A.2d 1020 (Md. 2004) ("Petitioner's appearance before a District Court judge for the purpose of setting the appropriate amount of bail pursuant to Md. Rule 4-216 is not such a 'critical' stage of the proceedings requiring that counsel be provided." (internal citation omitted)); Colbert, The Illusory Right, supra note 218, at 37-38 (collecting appellate court decisions rejecting the right to counsel at bail hearings); ANDREw V. JEzIC ET AL., The SiXTH Amendment Right to CounSEL, MD L. OF CONFESSIONS $§ 20: 1$ (2012) (considering whether Rothgery will cause state courts to revisit issue of whether bail review is a critical stage). In Smith v. Lockhart, relying on Hamilton v. Alabama, 368 U.S. 52, 54 (1961), the federal court of appeals held that an omnibus hearing at which defendant moved to reduce bail was a "critical stage;" however, this hearing also served as the proceeding at which certain defenses had to be raised or they would be irretrievably lost. 923 F.2d 1314, 1319-20 (8th Cir. 1991). In United States v. Frappier, a trial judge held that counsel performed deficiently at a bail hearing, but the Court does not address whether the bail hearing is actually a critical stage for which one is entitled to competent representation. 615 F. Supp. 51, 53 (D. Mass. 1985).

230 United States v. Wade, 388 U.S. 218, 227 (1967); see also Tinmouth, supra note 7, at 1610 (advocating for a narrow construction of the rights articulated in Strickland by focusing on the trial orientation of the right to counsel). 
such practical considerations, it is fair to question the jurisprudential dogma that there is no right to counsel in proceedings to determine whether a defendant will be incarcerated prior to his conviction. ${ }^{231}$ There is no question that the right to counsel has attached at the time of the bail hearing, and there is substantial support for the view that the pretrial detention has an impact on the accused's ability to obtain a fair trial. Professor Douglas Colbert has written the leading article on this question, making the case for regarding bail proceedings as a "critical moment in a criminal case" deserving of the protections promised by Gideon v. Wainwright. ${ }^{232}$

Colbert explains that the consequences of bail proceedings are among the most critical events in the course of a defendant's experience with the criminal justice system. For example, the "[1] ack of representation at the bail stage results in many accused individuals spending substantial time in jail on charges that are later dismissed, not prosecuted, or reduced." ${ }^{233}$ Likewise, "pretrial incarceration has a severe and often irreversible impact on employment and family relationships." ${ }^{234}$ In some instances, pretrial detention actually exceeds the maximum sentence for the charged offense, and in a case where the charges are ultimately dropped, "pretrial detention becomes a jail sentence for individuals who were never convicted." 235 Such impri-

231 Some lower court decisions seem to suggest that if the defendant could have shown that the failure to appoint counsel prejudiced the trial itself, the right to counsel would be violated. See, e.g., State v. Williams, 210 S.E.2d 298, 300 (S.C. 1974) (considering the likelihood to "prejudice the ensuing trial" as the critical inquiry); Green v. State, 872 S.W.2d 717, 720-21 (Tex. Crim. App. 1994) ("In essence, we must scrutinize any pre-trial event with a view to ascertaining whether presence of counsel is necessary to assure fairness and the effective assistance of counsel at trial, which is, after all, 'the core purpose of the counsel guarantee...." (internal citation omitted)).

232 See Colbert, The Illusory Right, supra note 218, at 1-58 (1998) (arguing that the right to counsel should apply to bail proceedings); see also Colbert, Empirical and Legal Case, supra note 218 , at 1720 (presenting a study demonstrating with "empirical data that the benefits of representation are measurable and that representation is crucial to the outcome of a pretrial release hearing"); $i d$. at 1747 (describing similar, though more anecdotal conclusions from the Manhattan Bail Project of the 1960s). Notably, Colbert does not directly address the Strickland problem, which makes sense because he is addressing the necessary antecedent question: is there a right to counsel simpliciter?

233 Colbert, The Illusory Right, supra note 218, at 6 (footnote omitted).

$234 I d$. ("Faced with the choice of being defended by an unprepared lawyer, many opt to plead guilty.").

235 Id. at $16 \mathrm{n} .66$ (discussing a case from Montana where a man was forced to serve sixty days of pretrial detention for traffic offenses). Likewise, in Rothgery v. Gillespie County, the accused was detained pretrial on charges of being a felon in possession of a firearm; however, as he was later able to show through the assistance of counsel, he was not a felon and thus the detention was entirely unjustified and the charges eventually dismissed. 554 U.S. 191 (2008). See Emily Chiang, Indigent Defense Invigorated: A Uniform Standard for Adjudicating Pre-Conviction Sixth Amendment Claims, 19 TemP. POL. \& CIV. RTS. L. REv. 443, 457-58 
sonment determinations made without the aid of counsel ought to be regarded as inherently suspect under the Sixth Amendment. ${ }^{236}$ But more importantly, for present purposes, Colbert discusses the relationship between a defendant's pretrial incarceration and the fairness of his trial and sentencing proceedings. Regarding the trial itself, Colbert's experience as a trial lawyer leads him to make the pragmatic observation that there is a critical difference "between appearing alone in an unfamiliar neighborhood looking for a prospective witness and arriving with a client who can dispel people's suspicions." ${ }^{237}$ Reasoning from observations like this, Colbert has little difficulty supporting the conclusion that representation in the service of securing one's pretrial release "impacts the likelihood of a fair outcome." ${ }^{238}$ Moreover, by relying on empirical data, Professor Colbert has elaborated on the relationship between bail proceedings and a fair trial by

(2010) (providing examples of pretrial detention that, without the assistance of counsel, become functionally equivalent to indefinite pretrial detention). Cf. United States v. Salerno, 481 U.S. 739, 751 (1987) (holding that pretrial detention does not violate due process as a general matter, but leaving open the possibility that inadequate procedures for determining eligibility for pretrial detention might violate due process).

236 Cf. Argersinger v. Hamlin, 407 U.S. 25,37 (1972) (holding that absent a waiver of counsel "no person may be imprisoned for any offense, whether classified as petty, misdemeanor, or felony, unless he was represented by counsel at his trial" (footnote omitted)).

237 Colbert, The Illusory Right, supra note 218, at 18. Lurking not far below the surface of a vision of the right to counsel that is divorced from concerns about the adequacy or fairness of the trial is the harmless error doctrine. Presently, harmless error review is unnecessary because of the prejudice requirement built into Strickland. Cf. Bruce Andrew Green, Note, A Functional Analysis of the Effective Assistance of Counsel, 80 CoLuM. L. REv. 1053, 1053 (1980) (observing that pre-Strickland many courts adjudicating claims of ineffective assistance still required prejudice because of the general requirement of harmless error). However, if the right to counsel is entirely divorced from the trial itself, then perhaps the harmless error inquiry, which is focused on the fairness and accuracy of the verdict, would reemerge. See, e.g., Delaware v. Van Arsdall, 475 U.S. 673, 681 (1986) (explaining that some procedural or technical errors are "inevitable" and undeserving of remedy and that harmless error protects a defendant's right to a "fair trial, not a perfect one").

238 Colbert, The Illusory Right, supra note 218, at 18. Of course, the determination that fair trials require representation at the bail stage rests on the assumption that representation would, as a general matter, result in less pretrial detention. This conclusion is confirmed by an empirical study of the effect of pretrial representation conducted in Baltimore. Colbert, Empirical and Legal Case, supra note 218, at 1720. Summarizing the findings, a group of scholars provided as follows: For eighteen months at bail hearings, the Baltimore City Lawyers at Bail Project ("LAB") defended the liberty of nearly 4000 lowerincome defendants accused of nonviolent offenses. The study showed that more than two and one half times as many represented defendants were released on recognizance from pretrial custody as were unrepresented defendants. Additionally, two and one half times as many represented defendants had their bail reduced to an affordable amount. Indeed, delaying representation until after the pretrial release determination was the single most important reason for lengthy pretrial incarceration of people charged with nonviolent crimes. $I d$. 
explaining that "incarcerated defendants invariably receive more severe sentences than individuals released on recognizance or affordable bail." ${ }^{239}$ Moreover, "when the accused remains in jail, the lawyer's ability to conduct a thorough investigation is impaired," and the absence of an early and thorough investigation can substantially prejudice an individual's defense at trial. ${ }^{240}$

There is, in short, a substantial concern that a person left without counsel at the bail hearing is more likely to be held in pretrial detention, and the effect of such detention is to substantially "derogate from the accused's right to a fair trial." ${ }^{241}$ And concerns like these regarding the ultimate fairness of the trial have led criminal procedure luminaries like Yale Kamisar and Wayne LaFave to urge an understanding of the bail hearing as a critical stage. ${ }^{242}$ LaFave's criminal procedure treatise reasons: "Because counsel for the defendant can make such an impact at the bail hearing, there is much to be said for the contention that the Sixth Amendment right to counsel applies at that time." ${ }^{243}$ In short, there are compelling arguments in favor of regarding the bail hearing as the sort of proceeding that occurs postattachment and that is critically important to the ultimate ability of the defendant to receive a fair trial facilitated by the effective representation of counsel. And yet, to date, courts have refused the invitation to regard the pretrial bail determination as a stage of the criminal prosecution requiring the appointment and effective assistance of counsel. This may soon change in light of the promise of a new era

239 Colbert, The Illusory Right, supra note 218, at 13.

$240 I d$. at 18. Admittedly, a similar argument can be made regarding the attachment rule. By refusing to hold that the right to counsel attaches at the time of arrest, or investigation, a defendant's efforts at trial may be hindered, and yet the Court has unequivocally rejected the view that this represents an affront to the right to counsel. See, e.g., Kirby v. Illinois, 406 U.S. 682, 689 (1972).

241 United States v. Wade, 388 U.S. 218, 226 (1967) (defining critical stage as "any stage of the prosecution, formal or informal, in court or out, where counsel's absence might derogate from the accused's right to a fair trial" (footnote omitted)).

242 See, e.g., Yale Kamisar et al., Modern Criminal Procedure: Cases, Comments And QUESTIONS 872 n.8 (8th ed. 1994).

243 LAFAVE ET AL., supra note 17, at $\$ 12.1$ (c). Likewise, the reasoning of the Court's decision in Coleman v. Alabama regarding the right to counsel at a preliminary hearing substantially supports the view that a bail determination ought to be regarded as a critical stage of the criminal proceedings, and thus warranting the appointment of counsel. 399 U.S. 1, 10 (1970). Moreover, in his concurrence in Coleman, Justice Black notes that there is a specific right to counsel guarantee in the Sixth Amendment, but the vague protections of "fair trial" are "conceived by judges" and not by the text of the Constitution. Id. at 12 . In his view, judges ought not "add to or detract" from the explicit commands of the Bill of Rights, and given that, a bail hearing is an obvious part of the "criminal prosecutions." $I d$. 
of constitutional pretrial effective assistance rights as announced in Lafler and Frye.

On the one hand, if it is accepted that one's representation at the bail determination hearing has an impact on the ultimate fairness of the trial, then even under the narrowest construction of the right to counsel, the right to effective assistance should apply to this proceeding. Moreover, even accepting the conclusions of several of the Court's current Justices that pretrial release is unrelated to the fairness of the trial itself, ${ }^{244}$ embracing the new era of effective assistance ushered in by Frye and Lafler might, nevertheless, require effective assistance of counsel at this proceeding. Frye and Lafler make clear that in demonstrating a reasonable probability of a different outcome, the reliability and fairness of the trial are not the only outcomes that count. Insofar as Frye and Lafler reflect a new, more capacious view of the range of outcomes that are relevant to an ineffective assistance of counsel inquiry, the errors of counsel at a bail determination may soon be a constitutionally cognizable basis for relief.

On the other hand, both Frye and Lafler present circumstances where the defendant was able to show that the errors of counsel likely resulted in a less favorable ultimate outcome-that is a verdict or sentencing outcome. Consequently, the bail determination may well serve as a bellwether for assessing just how broadly the new era of pretrial effective assistance sweeps. It is clear that outcomes unrelated to the fairness of the trial can give rise to Sixth Amendment violations, but the next question is whether outcomes-such as pretrial incarceration-unrelated to both one's trial and one's sentence could provide a cognizable basis for relief.

\section{Lack of Jurisdiction and Double Jeopardy}

Courts are understandably reluctant to nullify a guilty verdict, particularly when the verdict followed a full and fair trial. And yet, the new era of effective assistance tolerates, indeed requires, the nullification of procedurally adequate and reliable trial verdicts when certain pretrial proceedings were constitutionally inadequate. In an effort to flesh out the implications of a new, broader era for the right to pretrial effective assistance, I have discussed three types of claims: inadequate representation resulting in deprivations of one's Batson rights, inadequate representation resulting in deprivations of one's speedy trial rights, and errors of counsel that resulted in pretrial de-

244 See, e.g., Rothgery v. Gillespie Cnty., 554 U.S. 191, 213 (2008) (Alito, J., concurring). 
tention. None of these claims will result in relief if Strickland is construed as a merits or trial-focused protection, ${ }^{245}$ but each provides a colorable, if uncertain, basis for relief in light of Frye and Lafler. A fourth category of claims for pretrial ineffective assistance, and one that seems particularly strong, is that set of claims relating to a defendant's entitlement to relief when counsel's errors are of such a fundamental and structural nature as to undermine the legitimacy of the proceeding itself.

Where counsel's errors relate to the core authority of a court to impose criminal sanctions, then reversal of a conviction is warranted, and Strickland seems an appropriate vehicle for such reversal. Claims of this nature would include, for example, the failure of counsel to challenge a court's jurisdiction; or the failure of counsel to dismiss a charge that attempts to impose criminal punishment for conduct that is actually not a crime under the laws of the jurisdiction; or, less clearly, cases where defense counsel fails to dismiss charges for which the defendant has already been convicted in prohibition of double jeopardy.

One could argue that there is little distinction between counsel's errors resulting in the deprivation of a speedy trial claim and the error of failing to dismiss for lack of jurisdiction or for double jeopardy. To be sure, the distinction between these scenarios is not obvious, and perhaps not legally relevant. But, on the other hand, there does seem to be something different, something more technical or procedural, about a speedy trial deprivation. When a defendant is tried a second time for the same offense, particularly when he was convicted the first time, the proceeding itself seems fundamentally unfair in a way that a trial tainted by delay might not. Likewise, when the defendant is convicted for conduct that is not actually a crime, or when the trial court lacked jurisdiction, the conviction itself, though nominally reliable insofar as the jury reached a verdict, is intolerable as a matter of fundamental fairness. ${ }^{246}$

245 See, e.g., Williams v. Taylor, 529 U.S. 362, 396 (2000) (requiring adequate and reasonable pretrial investigation); Manning v. Warden, La. State Penitentiary, 786 F.2d 710, 712 (5th Cir. 1986) (requiring a showing that "prejudice" resulted from "the alleged misjoinder").

246 The view that failures to challenge fundamental defects in the charging authority of the prosecution or the jurisdiction of the court are the sort of attorney errors that are cognizable under the Sixth Amendment finds support in Coleman v. Alabama, 399 U.S. 1, 9 (1970). In holding that the preliminary hearing was a critical stage the Court stressed, among other things, that at a preliminary hearing the "lawyer's skilled examination and cross-examination of witnesses may expose fatal weaknesses in the State's case ...." Id. Notably, however, any weaknesses in the State's case that might have led "the magistrate to refuse to bind the accused over" would generally be of no consequence if the defen- 
However, if the claims amount to an assertion that the defendant's trial violates core notions of fairness, then one could plausibly argue that such claims, rare as they may be, are deserving of relief as a matter of due process and the promise of fundamental fairness, not as a product of the right to counsel. ${ }^{247}$ Indeed, the most limited understandings of the proper application of federal habeas review acknowledge that due process prohibits convictions beyond a court's authority, and thus appears to provide a workable theory of relief. ${ }^{248}$ There are, however, at least two hurdles to vindicating such errors of counsel through due process rather than through the right to counsel. First, such an approach might be in tension with the general canon of construction that a specific constitutional provision must trump the more general; ${ }^{249}$ the defect with the conviction is linked most directly to the errors of counsel in failing to raise the issue, after all. Second, the doctrine of procedural default would encumber a due process claim. ${ }^{250}$ That is not to say that the procedural default

dant was eventually tried and convicted through a fair trial一that is to say, the conviction beyond a reasonable doubt at a fair trial renders the inefficacy of counsel at the preliminary hearing harmless as to the ultimate outcome in the case. Id. Thus, Coleman seems to implicitly recognize that the critical role of counsel at this stage is to assess whether the accusatory instrument is fundamentally deficient based on jurisdictional or similar defects in the charges.

247 In urging a limited system of post-conviction review that permitted relief only when the prisoner had a colorable claim of innocence, Judge Friendly recognized an exception when the trial court lacked jurisdiction. Henry J. Friendly, Is Innocence Irrelevant? Collateral Attack on Criminal Judgments, 38 U. CHI. L. REv. 142, 160 (1970).

248 For example, Justice Thomas explained in Wright $v$. West that, based on his understanding of the common law, a prisoner could not bring a federal habeas corpus challenge "[a]bsent an alleged jurisdictional defect." 505 U.S. 277, 285 (1992); see also Paul M. Bator, Finality in Criminal Law and Federal Habeas Corpus for State Prisoners, 76 HARV. L. REv. 441, 450 (1963) (recognizing that even under a limited vision of federal habeas corpus, failures of process and failures of jurisdiction, among other things, warrant federal intervention and oversight).

249 See, e.g., Albright v. Oliver, 510 U.S. 266, 273 (1994) ("Where a particular Amendment 'provides an explicit textual source of constitutional protection' against a particular sort of government behavior, 'that Amendment, not the more generalized notion of 'substantive due process,' must be the guide for analyzing these claims." (internal citation omitted)); id. at 276 ("[Substantive due process] cannot be used to impose additional requirements upon such of the States' criminal processes as are already addressed (and left without such requirements) by the Bill of Rights." (internal citation omitted)).

250 There is a danger of substantial circularity in this analysis. Procedural defaults can be excused by a showing of cause and prejudice, and the cause and prejudice necessary to overcome a procedural default is satisfied by ineffective assistance of counsel. Murray v. Carrier, 477 U.S. 478 (1986) (holding that a freestanding claim of ineffective assistance must be exhausted in order for the ineffective assistance to serve as cause to excuse the default). Brian R. Means, Federal Habeas Manual $\$ 9$ B:74 (2008). It should be noted that demonstrating ineffective assistance of counsel as a basis to excuse a procedural default may provide a role for slightly weaker claims of ineffective assistance because Sixth 
could not be overcome, but only to suggest that it is a less direct challenge to the constitutional problem with the trial. ${ }^{251}$

More importantly, it seems that claims of pretrial effective assistance alleging that counsel failed to challenge the trial court's fundamental authority to conduct a trial provide a sound basis for Strickland relief. ${ }^{252}$ Even prior to Lafler and Frye the lower courts that addressed such claims appear to have been unanimous in holding that Strickland relief was available. For example, in a recent case, defense counsel failed to object to an indictment charging a crime that was not "legally cognizable," and on federal habeas review, a judge had little difficulty concluding that the defendant's conviction should be reversed based on ineffective assistance of counsel: "It is axiomatic that the elements alleged [in an indictment] must amount to an offense." ${ }^{253}$ Whether the conviction resulted from a guilty plea or a fair trial, this conclusion seems unassailable in light of Frye and Lafler.

Similarly, the conclusion that failures by counsel to move for the dismissal of a case for lack of jurisdiction can give rise to ineffective assistance of counsel claims is beyond reproach. ${ }^{254}$ Surely, the reasonable probability that the errors of counsel resulted in a plea or a trial that was otherwise jurisdictionally barred, no less than the errors of counsel causing the defendant to forego a favorable plea offer, can amount to a Sixth Amendment violation. Likewise, as Professor Jack Chin has observed, "collateral relief as ineffective assistance of trial counsel" has generally succeeded where counsel failed to dismiss

Amendment claims raised as cause to overcome a default need not themselves satisfy the onerous standard of review set out for habeas cases in 28 U.S.C. $\$ 2254(d)$.

251 Presumably a colorable claim that counsel failed to prevent his client from pleading guilty based on conduct that was not criminal would be excused by the miscarriage of justice exception to the procedural default rules. Murray, 477 U.S. at 496 ("[I]n an extraordinary case, where a constitutional violation has probably resulted in the conviction of one who is actually innocent, a federal habeas court may grant the writ even in the absence of a showing of cause for the procedural default.").

252 Cf. United States v. Garcia-Valenzuela, 232 F.3d 1003 (9th Cir. 2000) (recognizing that jurisdictional defects are not waived even by a guilty plea).

253 Williams v. United States, 684 F. Supp. 2d 807, 823 \& n.161 (W.D. Tex. 2010) (footnote omitted) (granting relief even though the defendant had pled guilty to the charge because counsel was deficient in failing to realize that "conspiracy to attempt to possess with intent [to] distribute was not a cognizable offense").

254 See, e.g., Thomas v. United States, No. 1:08-CV-307, 2010 WL 2349209 (W.D. Mich. June 7, 2010) (assuming that lack of jurisdiction would provide a basis for establishing a Strickland violation); Finley v. Nixon, No. 4:06CV1013-TIA, 2009 WL 3170455 (E.D. Mo. Sept. 25, 2009) (recognizing that the failure of counsel to challenge the state court's jurisdiction as having been lost under the Interstate Agreement on Detainers was a colorable basis for an ineffective assistance of counsel claim); Taylor v. United States, Nos. 3:09CV89-1-W, 3:05CR297, 2009 WL 2170351 (W.D.N.C. July 20, 2009); Freemont v. United States, No. 8:99CR183, 2002 WL 202084 (D. Neb. Feb. 8, 2002). 
charges that were brought in violation of the Fifth Amendment's double jeopardy prohibition. ${ }^{255}$ Stated differently, although the Court has repeatedly emphasized that the "strategic choices" of defense counsel "are virtually unchallengeable" under Strickland, ${ }^{256}$ a viable "strategy justification is more difficult to hypothesize ... where counsel failed to raise a claim of apparent merit which would have resulted in dismissal of the charges with prejudice" such as for a lack of jurisdiction, or double jeopardy. ${ }^{257}$

In short, to the extent there was any uncertainty as to the status of Sixth Amendment claims predicated on the failure of counsel to dismiss a charge for something akin to double jeopardy or jurisdictional bars, this uncertainty is no more. In the wake of the Court's recent decisions there is considerably more doctrinal clarity and consistency as to the scope of pretrial effective assistance rights.

\section{CONCLUSION}

The right to pretrial effective assistance of counsel is at a critical crossroads in its doctrinal life. Recent cases provide authority for a broad construction of the right to effective assistance, such that the right is increasingly regarded as valuable for its own sake, and not merely as an adjunct to the fair trial right. To date, however, the consequences of a non-trial-focused right to counsel have gone unexamined. This Article is a first attempt to expound on the implications of a right to pretrial effective assistance that is not oriented solely towards protecting the fairness of the trial and the reliability of the verdict.

The practical consequences of a broad construction of Strickland in the pretrial context may prove to be one of the most significant criminal procedure developments in decades. A number of procedural rights-such as the jury selection rights and the right to a speedy trial, for example-rely for their vindication on the effective assis-

J. Chin, Double Jeopardy Violations as "Plain Error" Under Federal Rule of Criminal Procedure 52(b), 21 PEPP. L. REV. 1161, 1180 n.111, 1181 (1994) (collecting cases across the circuits applying such an analysis); see also Rice v. Marshall, 816 F.2d 1126 (6th Cir. 1987) (applying ineffective assistance to a collateral estoppel form of double jeopardy violation).

256 Strickland v. Washington, 466 U.S. 668, 690 (1984).

257 Chin, supra note 255, at 1180 n.111 (quoting 3 WAYNE R. LAFAVE \& JEROLD H. ISRAEL, CRIM. PROC. $\$ 11.10$ (c) at 51 (West Supp. 1991)). Such strategies are similarly unavailable when counsel fails to dismiss a case on speedy trial grounds; however, there is, I maintain, a colorable difference between claims relating to the core authority of the court to hear a case and a speedy trial deprivation, though admittedly the distinction might be more theoretical than real. 
tance of counsel, and yet these rights do not directly implicate the fairness of the trial itself. In the wake of Frye and Lafler, courts must be guided by the insight that the purpose of the right to counsel is not merely to ensure a fair trial. No longer is the fairness of the conviction or the reliability of the trial dispositive to the Sixth Amendment inquiry. These developments mark a substantial shift, and a new era for the right to effective assistance. ${ }^{258}$

258 See, e.g., Lafler v. Cooper, No. 10-209, slip op. at 4 (U.S. Mar. 21, 2012) (Scalia, J., dissenting) (summarizing the authority that "until today" made it "entirely clear" that the right to counsel served the ends of reliable verdicts and fair trials). 
